\title{
The Constitutionality of Residence Tests for General and Categorical Assistance Programs ${ }^{\dagger}$
}

\author{
Bernard Evans Harvith*
}

\begin{abstract}
N THE United States, constitutional rights are being infringed by 1 residence tests for eligibility for state and federal welfare assistance. "Residence test" here, and throughout this paper, refers to a period of residence in a state necessary to qualify a person for welfare payments. These tests are derived historically from the concept of settlement, the idea that eacl individual belonged to a certain place which had the obhigation of supporting him in time of need. ${ }^{1}$ This concept is traceable to the English poor laws. ${ }^{2}$ While this article does not deal specifically with other derivatives of the settlement tradition, such as removal ${ }^{3}$ and "warningout," mucl of the analysis is applicable to these provisions.
\end{abstract}

Also, this article does not analyze extensively the validity of a requirement of residence, with no minimum period being required. The fourteenth amendment makes residence the determining factor for state citizenship ${ }^{5}$ and some of the arguments made here may founder in the face of the reasonableness of a distinction between citizens and noncitizens of a state.

First, this article will examine the constitutionahty of residence tests for general or public assistance, ${ }^{6}$ a form of welfare program entirely fi-

*A.B., 1960, University of Rochester; LL.B., 1963, Harvard University; LI.M., 1964, New York University. Visiting Assistant Professor of Law and Legal Director, Project on Social Welfare Law, New York University School of Law.

t This paper was prepared as part of the author's work for the Project on Social Welfare Law. The views expressed are the responsibility of the author.

The author is indebted to Professor Charles Ares, New York University School of Law and Professor Arvo Van Alstyne, University of California at Los Angeles, for their comments upon the conference draft of this paper.

1 See Mandelker, The Settlement Requirement in General Assistance, 1955 WASH. U.L.Q. $355-56$.

2 See id. at 355, 356-57.

${ }^{3}$ See generally Mandelker, Exchusion and Removal Legistation, 1956 WIs. L. Rev. 57.

4 See Mandelker, The Settlement Requirement in General Assistance, 1956 WASE. U.L.Q. 21-22.

E U.S. ConsT. amend. XIV, $\$ 1$.

6 The constitutionality of residence tests for general assistance is discussed in TENBRoEK, The Constitution and The Riget of Free Movearent (1955) [hereinafter cited as TENBROEr]; LoGatto, Residence Laws-A Step Forward or Backward?, 7 Catholic LaW. 101 (1961) [hereinafter cited as LoGatto]; Feinberg, Settlement Laws: A Constitutional Assault (unpublished paper prepared in 1964 by student at New York University School of 
nanced by state and local units and defined by state legislation. According to a compilation publislied in $1961,{ }^{7}$ residence tests for general assistance range from five years ${ }^{8}$ to no required period. ${ }^{0}$ States frequently require on $\mathrm{e}^{10}$ or three ${ }^{11}$ years of residence. Some require that the residence be in the county, ${ }^{12}$ and others require a shorter period in the county or township in addition to the longer period in the state. ${ }^{13}$ One variant is to require a shorter period for those who were self-supporting when they became residents. ${ }^{14}$ Other states have emergency provisions making assistance available in certain cases to those who do not meet the residence test. ${ }^{15}$ The constitutional validity of residence tests for general or public assistance will be considered in the face of challenges based upon: (1) a freedom of interstate movement which may be protected against state action by the commerce clause, ${ }^{\mathbf{1 0}}$ the privileges and immunities clause of the fourteenth amendment, or the privileges and immunities clause of article IV, or (2) the equal protection clause of the fourteenth amendment.

Second, this article will discuss the validity of residence tests for categorical assistance programs, which are defined in the Social Security Act and involve federal financial participation in state plans meeting specified federal standards. Categorical assistance programs ${ }^{17}$ include: (1)

Law) [hereinafter cited as Feinberg]; Hohlt, Residence Requirements: Are They Unconstitutional? (unpubhshed paper prepared in 1965 by student at Columbia Law School) [hereinafter cited as Hohlt]; Nathanson, Residence Requirements in Public Welfare Law (unpublished paper prepared in 1965 by student at Columbia Law School) [hereinafter cited as Nathanson]; Pierson, The Constitutionality of District of Columbia Residence Requirements for Public Assistance (undated mimeographed memorandum) [hereinafter cited as Pierson]; Note, 12 Wyo. L.J. 50 (1957). See also, on freedom of movement generally, Chafee, Three Human Rights in the Constitution of 1787, at 162-213, 221-23 (1956).

7 National Travejers am Ass'n, One Manner of Law-A Handbook on Residence Requireanents in Public Assistance 8-13 (1961).

8 E.g., N.H. REv. Stat. ANN. § 164:1 (1964 Replacement ed.).

o E.g., Hawair Rev. Laws § 108-15 (Supp. 1963); N.Y. Soc. Wetfare Law \$§ 117, 131, $132,138,139,157,158$.

10 E.g., Alaska Comp. Laws ANN. $\$ 47.25 .300$ (1962).

11 E.g., CaI. Welfare \& InsT'Ns Code $\$ 2555$.

12 E.g., Iowa Code $\$ 252.16$ (Supp. 1965).

13 E.g., IND. ANn. STAT. § 52-147 (1964).

14 VA. CODE ANN. \& 63-330 (1950).

15 E.g., Ore. Rev. Stat. § 411.720 (Supp. 1963).

16 U.S. Const. art. I, $\S 8$, cl. 3 .

17 The Social Security Act, 49 Stat. 620 (1935), as amended, 42 U.S.C. $\$ \S 301-1394$ (1964), as amended, 42 U.S.C. $\S \S 301-1396 d$ (Supp. I, 1965), is the focus of much of the discussion in this article. For discussion of the structure and administrative operation of the Social Security System, see Wedemeyer, The American Welfare System, this symposium. 
Old Age Assistance, ${ }^{18}$ (2) Aid to the Blind, ${ }^{19}$ (3) Aid to the Disabled, ${ }^{20}$ (4) Medical Assistance for the Aged, ${ }^{21}$ (5) programs combining any of the foregoing, ${ }^{22}$ (6) Aid to Needy Families with Children, ${ }^{23}$ and (7) Medical Assistance under Title XIX. ${ }^{24}$ State plans qualify for federal financial participation if, in regard to the first three of these programs (or any or all of them in a combined program), any residence test imposed does not exceed five of the nine years immediately preceding application, and continuous residence during the last year. ${ }^{25}$ A qualifying Aid to Needy Families with Children state program may impose only a residence requirement not exceeding one year, or in the case of a child under age one, not exceeding one year of residence, before the child's birth, by the parent or other relative with whom the child is living. ${ }^{26}$ Medical Assistance for the Aged and Title XIX Medical Assistance Plans qualify only if open to all residents of the state, ${ }^{27}$ so these programs are removed from consideration in this article.

According to a compilation published in 1961, state programs for. the types of categorical assistance allowing residence tests range from having the maximum tests allowable to having no residence tests. ${ }^{28}$ This article will examine the constitutionality of residence tests for categorical assistance in light of (1) a freedom of interstate movement protected against federal government interference, and (2) the equal protection of the law safeguarded by the due process provision of the fifth amendment.

18 Social Security Act, Title I, 49 Stat. 620 (1935), as amended, 42 U.S.C. \$\$ 301-06 (1964), as amended, 42 U.S.C. \$\$ 302-06 (Supp. I, 1965).

19 Social Security Act, Title X, 49 Stat. 645 (1935), as amended, 42 U.S.C. \$\$ 1201-06 (1964), as amended, 42 U.S.C. \$§ 1202-06 (Supp. I, 1965).

20 Social Security Act, Title XIV, 64 Stat. 555 (1950), as amended, 42 U.S.C. $\$ \$ 1351-55$ (1964), as amended, 42 U.S.C. $\$ \$ 1352-55$ (Supp. I, 1965).

21 Social Security Act, Title I, 49 Stat. 620 (1935), as amended, 42 U.S.C. $\$ \S 301-06$ (1964), as amended, 42 U.S.C. \$\$ 302-06 (Supp. I, 1965).

22 Social Security Act, Title XVI, 76 Stat. 197 (1962), 42 U.S.C. $\S \S 1381-85$ (1964), as amended, 42 U.S.C. $\$ \S 1382-85$ (Supp. I. 1965).

23 Social Security Act, Title IV, 49 Stat. 627 (1935), as amended, 42 U.S.C. $\$ \S 601-09$ (1964), as amended, 42 U.S.C. $\S \S 602-06$ (Supp. I, 1965).

24 Social Security Act, Title XIX, 79 Stat. 343, 42 U.S.C. §§ 1396-96d (Supp. I, 1965), providing for qualifying state plans for Medical Assistance to the aged, blind, disabled, and families with dependent children.

2549 Stat. 620 (1935), as amended, 42 U.S.C. $\S 302$ (b)(2) (1964); 49 Stat. 645 (1935), as amended, 42 U.S.C. $\S 1202(\mathrm{~b})(1)_{e}(1964) ; 64$ Stat. 555 (1950), as amended, 42 U.S.C. $\S 1352$ (b)(1) (1964); 76 Stat. 198 (1962), as amended, 42 U.S.C. $\$ 1382$ (b)(2) (1964).

2049 Stat. 627 (1935), as amended, 42 U.S.C. \& 602(b)(2) (1964).

2749 Stat. 620 (1935), as amended, 42 U.S.C. $\S 302$ (b)(2) (1964); 76 Stat. 198 (1962), as amended, 42 U.S.C. $\$ 1382$ (b) (2) (1964) (Medical Assistance to the Aged in combined program under Title XVI) ; 79 Stat. 349, 42 U.S.C. § 1396a(b) (3) (Supp. I, 1965).

28 National Travelers afd Ass's, One Manner of Law-A Handbook on Residence Requireanents in Public Assistance 8-13 (1961). 
THE CONSTITUTIONALITY OF RESIDENCE TESTS FOR GENERAL ASSISTANCE PROGRAMS

A variety of federal constitutional provisions may be cited in support of an attack on the validity of residence tests for state general assistance programs. However, it is important not to lose sight of the forest as we investigate particular hoary oaks and tiny seedlings of legal doctrine. Fortunately, the grounds for attack can be grouped in two general categories: (1) an infringement of a constitutionally protected freedom of movement, and (2) a denial of equal treatment of newcomers as compared to settled residents of the state. Before analyzing these categories, it will be useful to examine the very limited case law directly in point, to dispose of a spurious argument, and to distinguish one case.

\section{A. Cases Directly in Point}

\section{The One Direct Authority}

In People ex rel. Heydenreich v. Lyons, ${ }^{20}$ in 1940, the Supreme Court of Illinois upheld a state statute requiring applicants for assistance to have resided in the city or other pertinent local governmental unit for the three years immediately preceding the date of apphication. The court pointed out that since a state has no constitutionally imposed or common law duty to provide assistance, ${ }^{30}$ "a large degree of discretion rests upon the State when it elects to furnish relief. ${ }^{131}$ In analyzing a claim that the test denied equal protection, the court stated: "The Fourteenth Amendment .... nierely requires that the classification shall be based on a real and substantial difference having a rational relation to the subject of the particular legislation." ${ }^{\prime 2}$ The court found that the legislative purpose underlying the residence test was to guard against the costs of providing assistance payments to an "influx of unfortunate transients"; that is, to reduce the financial burden of assistance and to prevent any need for "reducing the aid to which permanent residents of Illinois should justly have first claim." ${ }^{\prime 33}$ Therefore, the residence test was held to be a reasonable classification, made pursuant to a valid state purpose. This holding was facilitated by the fact that the court construed the residence test so as to renove the discriminatory aspects being alleged by the parties. The relators, in general, seem to have met even a strict interpretation of the residence test except for short periods when they were absent

29374 III. 557, 30 N.E.2d 46 (1940).

30 Id. at 564-66, 30 N.E.2d at 50-51.

31 Id. at 565,30 N.E.2d at 51 .

32 Id. at 564,30 N.E.2d at 51 .

33 Id. at 566,30 N.E.2d at 51 . 
from their usual residence to seek and pursue work, when employment was not available near their usual residence. ${ }^{34}$ The court's interpretation of the purpose of the legislature made residence largely a matter of intention. "To construe the statute so as to preclude a temporary departure from the particular governmental unit by persons who have long resided there would impute a harsh and unconscionable intent to the legislature." poor rehief purposes once acquired is not necessarily lost or defeated by a voluntary absence for the purpose of obtaining work." ${ }^{37}$

The court did not have to face the equal protection question squarely. Moreover, the landmark decision dealing with freedom to travel interstate, Edwards v. California, ${ }^{38}$ was not decided until a year later. Also, Heydenreich is only a state court opinion. All of these factors serve to reduce the value of this case as authority.

\section{The Chirillo Dissent}

In re Chirillo, ${ }^{89}$ a 1940 decision by the Court of Appeals of New York, found four justices dismissing a direct appeal challenging the constitutionality of a removal statute, since other issues were also involved. ${ }^{40}$ Three dissenting justices ${ }^{41}$ would have reached the constitutional issues and upheld the statute against arguments based on the due process, equal protection, and privileges and immunities clauses of the fourteenth amendment, the privileges and immunities clause of article IV, and the commerce clause.

The dissent argued that New York, before adoption of the Constitution, "possessed the powers of a sovereign nation, which included the power to refuse admittance to, or to deport, a person coming from without its borders, whether or not that person crossed the state hine with the intention of seeking permanent residence . . . ${ }^{32}$ The state retains this power, except as limited by the United States Constitution. Due process requires only that regulations promote "the public welfare through having a real and substantial relation to that end, and shall not be unreasonable, arbitrary or capricious." ${ }^{\prime 43}$ That the New York statute meets this

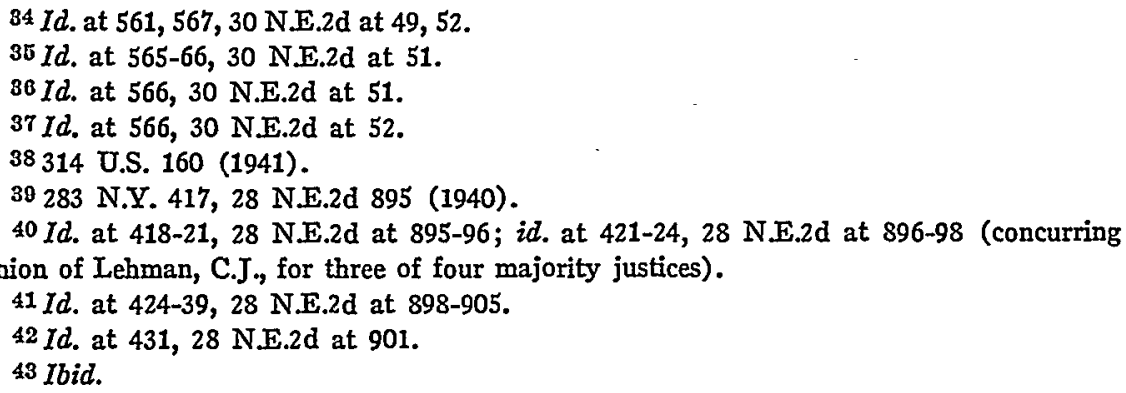


test is shown by: (1) the long history of removal legislation at common law, (2) the safeguards incorporated in the statute, and (3) the size and growth of the state's welfare burdens and its grants per person which exceed those of other states. ${ }^{44}$

The dissenters argued that the commerce clause does not, "in the absence of congressional pre-emptions," bar exercises of the police power "within reasonable restrictions, even though there may be interference with interstate commerce."45 The removal statute does not prevent any person from entering the state; removal is possible only after an apphication for welfare assistance. The privileges and immunities clause of article IV prevents a state from discriminating against another state's citizens.

To hold that this clause protects the right of a citizen to be supported at public expense in any community to which he may journey, it is necessary to find that there is inherent in State citizenship a constitutional right to be supported at public expense free from any limitations whatsoever. . . No such right exists. "Neither aliens nor citizens of other states are invested by the Constitution with any interest in the common property of the people of this state."140

There is no discrimination based on state citizenship, the dissent continued, since New York citizens applying for assistance may also be removed to their place of settlement if it is in another county. ${ }^{47}$ The same argument disposes of any claim that the equal protection clause is violated. The removal statute treats similarly all persons similarly located; that is, those applying for assistance. ${ }^{48}$ The privileges and immunities clause of the fourteenth amendment is inapplicable, since the privileges and immunities of United States citizens are only those resulting "from other provisions of the Constitution and from the laws of Congress." No federal statute applies and no other provision of the Constitution is violated.

\section{B. An Improper Argument: The Absence of a Duty to Enact Assistance Programs Allows a State to Condition Such Programs as It Wishes}

It is now necessary to dispose of the contention that, since neither the common law nor the state or federal constitutions impose a duty on a state to provide welfare assistance, the state can condition a grant of

44 Id. at $432-34,28$ N.E.2d at 901-02.

$45 I d$. at 435,28 N.E.2d at 903 .

$40 \mathrm{Id}$. at 436,28 N.E.2d at 903 .

47 Id. at 436-37, 28 N.E.2d at 903-04.

$48 I d$. at 437,28 N.E.2d at 904 .

$49 \mathrm{Id}$. at $438,28 \mathrm{~N} . \mathrm{E} .2 \mathrm{~d}$ at 904 . 
such assistance as it wishes, even in derogation of constitutional rights. ${ }^{50}$ If this contention is correct, the remainder of this article is a futile exercise.

The Chirillo dissent argued that removal, being possible only after an application for assistance, could not infringe any freedom to enter the state. ${ }^{51}$ The application for assistance would waive any constitutional right to free interstate movement, including the right to remain. An assistance applicant "is bound to accept the relief cum onere, or with the himitation of the reasonable provisions of the Public Welfare Law." ${ }^{252}$ It is unclear whether the dissenters were describing the conditions as "reasonable" or saying they were required to be so.

In Heydenreich, a power to condition assistance was recognized. The Illinois court stated that "since there is no legal obligation upon the State, ... in the absence of legislative action, to support its poor, it follows, necessarily, that a large degree of discretion rests upon the State when it elects to furnish relef." ${ }^{\prime 33}$ This discretion was considered broad enough to include residence tests.

The invahdity of this contention seems evident from the 1963 decision of the United States Supreme Court in Sherbert v. Verner, ${ }^{54}$ which held unconstitutional the application of a state unemployment compensation statute to deny benefits to a Seventh Day Adventist who could not find work because her religion prevented her from laboring on Saturday. The Court rejected an argument that since the compensation benefits were a privilege and not a right, the state could condition them even if a constitutional right is infringed thereby. ${ }^{55}$

Admittedly Sherbert, hike Speiser v. Randall, ${ }^{56}$ the major authority cited in support of the Court's holding, ${ }^{57}$ involved a condition operating "to inhibit or deter the exercise of First Amendment freedoms." It is well settled that such freedoms occupy a preferred position in the galaxy

50 See, e.g., People ex rel. Heydenreich v. Lyons, 374 IIl. 557, 30 N.E.2d 46 (1940). Contra, Reich, Individual Rights and Social Welfare: The Emerging Legal Issues, 74 YALE L.J. 1245, 1255-56 (1965). For a more complete analysis than that which follows, see O'Neil, Unconstitutional Conditions: Welfare Benefits With Strings Attached, this symposium. See also Linde, Constitutional Rights in the Public Sector: Justice Douglas on Liberty in the Welfare State, 40 WASH. L. REv. 10-34 (1965).

51283 N.Y. at 435,28 N.E.2d at 903.

52 Id. at 436, 28 N.E.2d at 903.

53374 III. at 565,30 N.E.2d at 51.

54374 U.S. 398 (1963) (7-2 decision, with Justices Douglas and Stewart each concurring separately, and Justices Harlan and White dissenting). See Feinberg 32-33; Note, Unconstitutional Conditions, 73 HARV. L. REV. 1595 (1960).

55374 U.S. at $404-06$.

56357 U.S. 513 (1958).

57374 U.S. at 405.

58 Ibid. 
of constitutional rights. ${ }^{50}$ However, since freedom of interstate movement has been analogized, in importance, to such freedoms, ${ }^{00}$ Sherbert is highly relevant to a consideration of the validity of residence tests for public assistance.

Sherbert conceivably could be distinguished on the ground that unemployment compensation is an insurance program, different in kind from assistance. However, the Court gave no indication that such a distinction would be siguificant. The underlying policy of the decision, opposition to allowing a state to either buy up constitutional rights or treat similarly situated persons differently, would seem equally applicable to the assistance situation.

The extent of the Court's protection of constitional freedoms is indicated by its express statement that conditions, "whatever their purpose," were invalid if they merely inhibited or deterred the exercise of first amendment freedoms. ${ }^{61}$ The Court did admit that there might be "some compelling state interest" which could justify such infringement, but "in this highly sensitive constitutional area, 'only the gravest abuses, endangering paramount interests, give occasion for permissible himitation,' . . . . No such abuse or danger has been advanced in the present case." ${ }^{\prime 22}$ While the majority stated that the only "danger" argued to them was that of fraudulent claims leading to dilution of the state's unemployment compensation fund, the dissent ${ }^{63}$ stressed the state's interest in accumulating funds, "when employment was available, to tide workers over jobless periods. ${ }^{64}$ Therefore, the holding in Sherbert would seem to blunt an argument that residence tests are justified to protect the state's treasury. The economic threat in Sherbert arguably was less than that caused by in-migrating indigents. But the holding in Edwards v. California ${ }^{06}$ would seem to destroy any attempt to stress the extent of an economic threat posed by such migrants. There, the Court acknowledged California's economic phight, resulting from heavy in-migration of poor refugees from the Dust Bowl. The majority held that aiding indigents to enter the state could not be barred for that reason, because of the commerce clause. The concurrmg justices reached a similar result, but applied the privileges and immunities clause of the fourteenth amendment. ${ }^{.0}$

50 E.g., Kovacs v. Cooper, 336 U.S. 77, 89-97 (1949) (concurring opinion of Frankfurter, J.) and cases cited therein; Freund, The Supreme Court of the United States 32-33, 74-87 (Meridian ed. 1961).

${ }^{80}$ Aptheker v. United States, 378 U.S. 500, 517 (1964).

01374 U.S. at 405.

02 Id. at 406-07.

63 Id. at 418.

64 Id. at $418-19$.

65314 U.S. 160 (1941).

${ }^{68} I d$. at $177,181$. 
Perhaps the only state purposes which can justify conditions infringing basic constitutional rights are efforts to ineet other fundamental human needs, such as a uniform day of rest, used in Sherbert ${ }^{67}$ to explain a Sunday law case. ${ }^{68}$

\section{A Distinguishable Case-Flemming v. Nestor}

Flemming v. Nestor, ${ }^{69}$ while distinguishable fron the situations of residence tests for general and categorical assistance, might be thought to contradict some of the analysis in this article. In Flemming, a five-tofour decision of the Supreme Court in 1960, five Justices, speaking through Justice Harlan, upheld a provision of the Social Security Act ${ }^{70}$ terminating old-age benefits for ahens deported from the United States for having been nrembers of the Communist Party. While this case dealt with a federal statute, the majority's reasoning might be thought to support the proposition that state or federal legislatures may restrict eligibility for public benefit programs as long as any arguably valid legislative purpose may be conjured up by the Court, regardless of either the actual intent of the legislators or the effect of the restrictions. Presumably, such an analysis of Flemming would explain Sherbert as an excep: tion confined to situations where the restriction infringes freedom of rehigion. Moreover, Flemming dealt with benefits which are easier to call vested rights than are those provided under assistance programs.

The majority rejected contentions that the statute violated the due process clause of the fifth amendment, the bans in article I, section 9 on bills of attainder and ex post facto laws, and the sixth amendment forbidding imposition of criminal punishment without a jury trial. They argued that the employee acquires no vested property rights from his payment of Social Security taxes, and that no punishment was involved, since the statute was aimed at "the activity or status from which the individual is barred," rather than "the person or class of persons disqualified."

In Flemming the majority applied very strong presumptions of constitutionality: (1) After stating that "the Due Process Clause can be thought to interpose a bar only if the statute manifests a patently arbitrary classification, utterly lacking in rational justification," Harlan inquired if there was a valid purpose which Congress miglit have been implementing. Having found such a motivation-the desire to

67374 U.S. at 408.

68 Braunfield v. Brown, 366 U.S. 599 (1961).

60363 U.S. 603 (1960).

70 Social Security Act $\S 202(\mathrm{n}), 49$ Stat. 623 (1935), as amended, 42 U.S.C. $\S 402(\mathrm{n})$ (1964).

71363 U.S. at 614.

72 Id. at 611. 
have Social Security payments spent in the United States to bolster national production, he argued that it was "constitutionally irrelevant whether this reasoning in fact underlay the legislative decision." 73 Therefore, the statutory classification was not arbitrary or irrational. (2) In considering the allegations that the statute imposes punishment and is a bill of attainder, ex post facto law, or violation of the sixth amendment, Harlan stated:

$[0]$ nly the clearest proof could suffice to establish the unconstitutionality of a statute on such a ground. Judicial inquiries into Congressional motives are at best a hazardous matter and when that inquiry seeks to go behind objective manifestations it becomes a dubious affair mdeed. Moreover, the presumption of constitutionality with which this enactment, like any other, comes to us forbids us lightly to choose that reading of the statute's setting which will invalidate it over that which will save it. ${ }^{74}$

The precedential value of Flemming for cases dealing with residence tests for assistance is weak for the following reasons:

(1) The statute in Flemming, unlike that in Sherbert, and unlike a residence test affecting freedom of movement, does not treat a person differently because he chose to exercise a preferred constitutional right. The Court had previously held that the conduct underlying the termination of old-age benefits was sufficient to justify deportation of an alien. ${ }^{75}$ Freedom of movenient has been analogized to first amendment rights. ${ }^{70}$

(2) Harlan's presumptions and conjuring up of a possible, valid legislative purpose are inconsistent with the Court's approach in Sherbert in 1963; $\mathrm{m}$ other first amendment cases, and especially those dealing with freedom of speech, to which freedom of novement has been analogized; ${ }^{77}$ in the 1963 decision in Kennedy v. Mendoza-Martinez, ${ }^{78}$ which, like Flemming, found the Court inquiring if the purpose of Congress was punishment; in Griffin v. County School Board of Prince Edward County $^{79}$ in 1964; and in Aptheker v. Secretary of State, ${ }^{80}$ also in 1964.

In Sherbert, the Court held that only a "compelling state interest" could justify infringing "appellant's First Amendment right. It is basic

73 Id. at 612 .

74 Id. at 617 .

75 Galvan v. Press, 347 U.S. 522 (1954).

70 Aptheker v. Secretary of State, 378 U.S. 500, 516-17 (1964) (majority opinion by Goldberg, J.) ; id. at 519,520 (concurring opinion of Douglas, J.).

77 See note 76 supra.

78372 U.S. 144 (1963). The author is indebted to Acting Associate Professor Robert M. O'Neil, of the University of California School of Law, Berkeley, for suggesting the relevance of this case to a discussion of the continued viabihty of the Court's attitude in Flemming.

79377 U.S. 218 (1964).

80378 U.S. 500 (1964). 
that no showing merely of a rational relationship to some colorable state interest would suffice; in this highly sensitive constitutional area, 'only the gravest abuses, endangering paramount interests, give occasion for permissible himitation.' "81 The Court stated that if it were to consider the justifications argued by the state, but not raised below, and "even if the possibility of spurious claims did threaten to dilute the fund and disrupt the scheduling of work, it would plainly be incumbent upon the appellees to demonstrate that no alternative forms of regulation would combat such abuses without infringing First Amendment rights."

The preferred position of first amendment freedoms, especially those of speech and press, has even led Justice Frankfurter to worry about an implication "that any law touching communication is infected with presumptive invalidity." 83 In any event, clearly no presumption of validity of the type indulged in by Harlan in Flemming would be applied to statutes challenged as infringing free speech. ${ }^{84}$

In Kennedy v. Mendoza-Martinez, Justice Goldberg's majority opinion investigates in detail and with care the legislative history of a federal statute and its antecedents, to determine if the purpose of Congress was to punish. ${ }^{85}$ Here is a search for the actual intent, rather than a possible intent which may have been chimerical, as in Harlan's opinion in Flemming. Mendoza-Martinez is especially significant since it was not a case involving first amendment freedoms.

In the Prince Edrvard County school case, the Court showed itself very willing to look througl a discriminatory statute to ascertain if racial discrimination was the motivating purpose. ${ }^{86} \mathrm{It}$ is certainly not illogical to assume that the justices will be as inquiring when the underlying aim might be to discriminate against the newcomer or to deter and penalize freedom of movement.

In Aptheker, ${ }^{87}$ the Court held applicable to congressional legislation affecting freedom of movement, the rule applied in first amendment cases $^{88}$ that the Court will examine the validity of a statute on its face and may "take into account possible applications of the statute in other factual contexts besides that at bar." 89 The attitude here is almost

81374 U.S. at 406.

82 Id. at 407 .

83 Kovacs v. Cooper, 336 U.S. 89, 90 (1949) (concurring opinion of Frankfurter, J.).

84 See McKay, The Preference for Freedom, 34 N.Y.U.L. REv. 1182 (1959).

85372 U.S. at $169-84$.

80377 U.S. at 231, where Justice Black based his determination as to purpose on his lengthy analysis of the record in the case.

87378 U.S. at $516-17$.

88 E.g., Winters v. New York, 333 U.S. 507, 518-20 (1948); Thornhill v. Alabama, 310 U.S. $88,97-98$ (1940).

89378 U.S. at 516, quoting NAACP v. Button, 371 U.S. 415,432 (1963). 
opposite that of Harlan in Flemming; according to Aptheker, the imagining will be of situations where the statute may apply unconstitutionally.

(3) The presumptions in Flemming will not apply where there is a clear manifestation of legislative intent, and such information does exist in regard to residence tests for assistance. ${ }^{90}$

(4) The actual purpose behind assistance residence tests, saving public funds by deterring the poor from migrating into the state and delaying the time when newcomers become eligible, is not a valid purpose, as will be argued in this article. The threat to the public purse argument was rejected by the Court in Edwards v. California ${ }^{01}$ in 1941. The Court stated in Sherbert ${ }^{92}$ that Flemming was distinguishable because of "the compelling federal interests" which underlay congressional enactment of the statute there challenged. In light of this statement and of the strong dissents in Flemming, ${ }^{93}$ it would seem that very compelling governmental purposes indeed will be needed, in the future, to support conditioning of public benefits in a way that affects important constitutional rights.

(5) Even if the Court were to search for a valid purpose which a legislature inight have had when passing assistance residence tests, no such purpose will be found, or at least no valid purpose will be found which could not be served by a much less restrictive statute, as this article will demonstrate, principally because of Edreards and the fourteenth amendment, which provides that all residents of a state, including newcomers, are citizens thereof. ${ }^{94}$

(6) Flemming did not deal with the rights of a member of the body pohitic, a person who was presently a United States and state citizen, or a resident of a state and of the United States. While not expressly so stating, the majority opinion smacks of the tang of earlier cases concerning the discretion of Congress in regard to deporting aliens. ${ }^{95}$ This distinction is especially important in regard to an attack of residence tests as denying equal protection. The fact of deportation on specific grounds may be a valid basis for discriminating against a person, but it is difficult to make the same argument in regard to the fact of interstate movement, since the fourteenth amendment makes all residents of a state, including newcomers, citizens thereof.

\footnotetext{
${ }^{90}$ See note 147 infra.

91314 U.S. 160 (1941).

82374 U.S. 398, 409 n.9 (1963).

93363 U.S. at 621 (Black, J.), 628 (Douglas, J.), 634 (Brennan, J., Warren, C.J., and Douglas, J.).

94 U.S. Covst. amend. XIV. § 1, cl. 1.

95 E.g., 363 U.S. at 616. An example of the earlier cases is Galvan v. Press, 347 U.S. 522 , 530-32 (1954).
} 
(7) In Flemming, four justices, a majority of those still sitting, ${ }^{96}$ would have held the statute unconstitutional. Justice Black ${ }^{97}$ argued it was a taking of property without just compensation, a violation of the due process clause of the fifth amendment, a bill of attainder, and an ex post facto law. Justice Douglas ${ }^{98}$ contended it was a bill of attainder, and he joined Justice Brennan and Chief Justice Warren ${ }^{99}$ in finding an ex post facto law and an imposition of a criminal punishment without a jury trial, in violation of the sixth amendment.

(8) While Nestor had a strong argument unavailable to the assistance applicant, deprivation of an accrued property right arising from payment of Social Security taxes, the Flemming majority rejected that view, ${ }^{100}$ although Black ${ }^{101}$ and Douglas ${ }^{102}$ would have held the statute invalid on grounds requiring the finding of such a right. Furthermore, the invalidity of assistance residence tests as (1) interfering with freedom of movement, and (2) denying equal protection, is not dependent upon the existence of a property right to assistance payments.

\section{Infringement of Freedom of Interstate Movement}

Invalidation of a residence test as an infringement of a freedom of interstate movement protected by the federal constitution requires two analytical steps: (1) determining the existence and constitutional basis of such a freedom, and (2) finding that the residence test is an improper infringement of that right. It seems logical to begin by estabhishing what is a vital portion of the second finding: that residence tests for general assistance do affect interstate movement. The same argument will, of course, apply to the impact of residence tests for categorical assistance.

Residence tests for general assistance prevent the interstate migration of persons unable to exist without public assistance in their new home for the period of residence required, if the potential migrant recognizes his situation and reacts sensibly. Residence tests also penalize those who do migrate for the fact of having noved interstate. Also, a clear distimction should be made between those persons whose only reason for migrating is to obtain higher assistance payments, and those persons who will be deterred from migrating if residence requirements in

86 Of the five-man majority, Justices Harlan, Clark and Stewart remain; Justices Frankfurter and Whittaker are no longer sitting.

97363 U.S. at 621-28. Although not listed as concurring in the dissents written by

Douglas and Brennan, Black stated that he agreed with the views expressed therein. Id. at 621 .

98 Id. at $628-34$.

$99 \mathrm{Id}$. at $634-40$.

100 Id. at 609-1I. This conclusion of the majority is criticized in Reich, The New Property, 73 YaLE L.J. 733, 769-71 (1964).

101363 U.S. at $623-25,627$.

102 Id. at 631-32. 
the new state would prevent them from receiving, for even a short period of time, their present level of assistance. The latter are not motivated by any desire to get higher payments, but must be included in an enumeration of persons prevented from migrating by residence tests.

Clearly, residence tests affect interstate movement. Therefore it is necessary to consider whether there is a freedom of interstate movement and if the effect of residence tests thereon is unconstitutional.

\section{The Commerce Clause}

The commerce clause of the federal constitution ${ }^{103}$ has been discussed by several writers ${ }^{104}$ as a ground for invalidating residence tests and other state legislation impeding a freedom of interstate movement of persons. This freedom amounts to a right not to have interstate movement of persons controlled by the states, absent an overriding state interest.

An argument built upon the commerce clause has two main components: (1) imterstate movement of persons is commerce, and (2) such commerce may be regulated only by Congress, with limited exceptions inapplicable to the assistance residence test situation. State regulation of the movement of persons, when necessary on grounds of health, ${ }^{105}$ is such an exception.

(a) The Edwards Case.-The case from which any analysis of assistance residence tests and freedom of movement must start, is $E d$ wards v. California. ${ }^{108}$ The nine justices of the United States Supreme Court agreed in the result, holding unconstitutional a state statute making it a misdemeanor knowingly to bring a nonresident indigent into the state. A majority of five, in an opinion by Justice Byrnes, based their conclusion on the commerce clause. ${ }^{107}$ They held that "the transportation of indigent persons from State to State clearly falls within ... [the class of subjects related to interstate commerce which can only be regulated by Congress]."108 Four justices (Justices Black and Murphy concurring in an opinion by Justice Douglas, ${ }^{109}$ and Justice Jackson concurring separately) ${ }^{110}$ thought the state statute invalid because it infrimged a freedom of interstate movement which is a privilege or

103 U.S. Const. art. I, \& 8, cl. 3.

104 E.g., Pierson III-A-3-9; Hohlt 10-11; TENBroEk 7-11; Feinberg 41-44.

${ }^{105}$ An extreme example of application of this exception is Compagnie Francaise de Navigation a Vapeur v. Louisiana State Bd. of Health, 186 U.S. 380 (1902). See TENBroEK 9. 108314 U.S. 160 (1941).

107 U.S. Const. art. I, $\S 8$, cl. 3.

108314 U.S. at 176.

100 Id. at 177 .

$110 \mathrm{Id}$. at 181. 
immunity of a United States citizen guaranteed against state abridgement by the fourteenth amendment. 111

The majority expressed no view contrary to the conclusion that freedom of movement is such a privilege or immunity, finding it unnecessary to reach that question. ${ }^{112}$ Also, Douglas' concurring opinion begins: "I express no view on whether or not the statute here in question runs afoul of Art. I, $\S 8 \ldots$. .113 Therefore, three concurring justices did not contradict the majority's view of the commerce clause. Only Justice Jackson disputed a ground for decision relied upon by another justice in this case. He thought the commerce clause inapplicable to "migrations of a human being."114 It is fair to summarize Edwards as representing a vote of 5-1 for finding a violation of the commerce clause and of 4-0 for finding a violation of the privileges and immunities guarantee of the fourteenth amendment.

The majority clearly repudiated Jackson's argument for rejecting the Court's reliance on the commerce clause: " $[I] t$ is settled beyond question that the transportation of persons is 'commerce,' within the meaning of that provision [the commerce clause]. "115 This conclusion was supported by citation of proper authorities. ${ }^{116}$

The established construction of the commerce clause was stated by Chief Justice Stone in Southern Pac. Co. v. Arizona: ${ }^{117}$

Ever since ... Cooley v. Board of Wardens, ${ }^{118}$. . it has been recognized that, in the absence of conflicting legislation by Congress, there is a residuum of power in the state to make laws governing matters of local concern which nevertheless in some measure affect interstate commerce or even, to some extent, regulate it ....

But ever since Gibbons v. Ogden, ${ }^{119}$... the states have not been deemed to have authority to impede substantially the free flow of com-

111 U.S. Const. amend. XIV, § I.

112 Justice Byrnes, after deciding the case under the commerce clause, stated: "In the view we have taken it is unnecessary to decide whether the Section is repugnant to other provisions of the Constitution." 314 U.S. at 177. That one of these other provisions was the privileges and immunities clause of the fourteenth amendment is shown by an examination of the summaries of the arguments of appellant, $i d$. at 163 ; of the amicus curiae, $i d$. at 164 ; and of appellee, $i d$. at 170.

113 Id. at 177 .

114 Id. at 182.

115 Id. at 172.

116 Id. at 172 n.1, citing Gloucester Ferry Co. v. Pennsylvania, 114 U.S. 196, 203 (1885); Leisy v. Hardin, 135 U.S. 100, 112 (1890); Covington Bridge Co. v. Kentucky, 154 U.S. 204, 218 (1894); Hoke v. United States, 227 U.S. 308, 320 (1913); Caminetti v. United States, 242 U.S. 470, 491 (1917); United States v. Hill, 248 U.S. 420, 423 (1919); Mitchell v. United States, 313 U.S. 80 (1941).

117325 U.S. 761, 766-67 (1945).

11853 U.S. (12 How.) 299 (1851).

11922 U.S. (9 Wheat.) 1 (1824). 
merce from state to state, or to regulate those phases of the national commerce which, because of the need of national uniformity, demand that their regulation, if any, be prescribed by a single authority.

As Professor Allison Dunham has remarked, "all modern cases say something similar to Chief Justice Stone's statement."120 Stone, discussing those phases of national commerce where uniformity requires exclusive congressional power, cited Edwards. ${ }^{121}$ Therefore, there seems to be no doubt that interstate movement of persons is a form of commerce which, generally, the states may not regulate.

In view of the "health" exception to the ban on state regulation of interstate inovement, it is significant that, in Edwards, the Court rejected a view of the poor as a "inoral pestilence."122

More important is the dictum of the majority: "The nature and extent of [a state's] . . obligation to afford relief to newcomers is not here involved. We do, however, suggest that the theory of the Elizabethan poor laws no longer fits the facts."123

(b) Crandall and Williams-Interference With Egress.-Crandall v. Nevada ${ }^{124}$ was decided inuch earlier than Edwards and before the passage of the fourteenth amendment. The Court mvalidated a state tax upon all persons leaving the state by commercial vehicle. The decision was based upon the needs of the country and the concomitant rights of its citizens that the latter be unhampered in approaching the seats of government, the courts, public offices, and seaports. ${ }^{125}$ Justice Stone, dissenting in Colgate v. Harvey ${ }^{\mathbf{1 2 6}}$ in 1935, in an opinion joined by

120 Dunham, Congress, the States and Commerce, 8 J. PuB. L. 47, 49 (1959). "For other expressions of this doctrine, see California v. Zook, 336 U.S. 725, 728 (1949); Citics Service Co. v. Peerless Co., 340 U.S. 179, 186 (1950)." Id. at 49 n.17.

121325 U.S. at 768.

122314 U.S. at 177. Paupers, vagabonds, and convicts were referred to as a "moral pestilence" in City of New York v. Miln, 36 U.S. (11 Pet.) 102, 142 (1837), discussed in Subsection $I I, D, 1$ infra. The view expressed in Edwards is consistent with Robinson v. California, 370 U.S. 660 (1962), where the Court invalidated a criminal law penalizing the status of being a narcotics addict and applying to a person "whether or not he has ever used or possessed any narcotics within the State, and whether or not he has been guilty of any antisocial behavior there." Id. at 666 . While this decision was based on the prohibition in the eighth amendment against cruel and unusual punishment (here apphed to the states through the fourteenth amendment), the underlying policy would also appear to run counter to any attempt to exclude the poor as a group.

123314 U.S. at 174.

12473 U.S. (6 Wall.) 35 (1867). One amazing aspect of this case is that Crandall, who had sought a writ of error, was not represented at the oral argument and no brief was filed on his behalf. Justice Miller noted this situation at the beginning of his opinion. Id. at 39 . The reasons underlying the Court's decision inust have been strong to have overcome the failure of Crandall to present any argument to the Court.

125 Id. at $43-44$.

126296 U.S. 404, 436 (1935) (dissenting opinion). The opinion from which Mr. Justice Stone dissented was subsequently overruled. Madden v. Kentucky, 309 U.S. 83 (1940). 
Justices Brandeis and Cardozo, discussed Crandall and stated: "No one could doubt that if the decision had been made at any time after Railroad Co. v. Maryland, ${ }^{127}$... and until the present moment, it would have been rested on the commerce clause."128

In Crandall, the Court considered the commerce clause argument and found it unconvincing:

It may be that under the power to regulate commerce among the States, Congress has authority to pass laws, the operation of which would be inconsistent with the tax imposed by the State of Nevada, but we know of no such statute now in existence. Inasmuch, therefore, as the tax does not itself institute any regulation of commerce of a national character, or which has a uniform operation over the whole country, it is not easy to maintain ... that it violates the clause of the Federal Constitution which we have had under review. ${ }^{129}$

Justice Miller then stated that the Court did not "concede" that the case had to be decided under the commerce clause. ${ }^{130}$ Moreover, as will be discussed later, Justices Douglas, Black and Murphy, concurring in Edwards, ${ }^{131}$ explicitly disagreed with Stone ${ }^{132}$ and interpreted Crandall as holding that "the right to move freely from State to State was a right of national citizenship," a right which upon the subsequent passage of the fourteenth amendment was protected by its privileges and immunities clause against state action. ${ }^{133}$

- Williams v. Fears, ${ }^{134}$ in 1900, found the Supreme Court again dealing with a state tax affecting egress. In upholding a Georgia statute taxing "emigrant agents," who hired persons in Georgia to work outside the

12788 U.S. (21 Wall.) 456 (1874).

128296 U.S. at 444. Justice Stone's statement is quoted with approval in Anderson v. Mullaney, 191 F.2d 123, 127 (9th Cir. 1951), aff'd on other grounds, 342 U.S. 415 (1952).

12973 U.S. (6 Wall.) at 43.

130 Ibid. Justice Miller also refused to "concede" that the case must be decided under article I, section 10, clause 2 of the Constitution: "No State shall, without the Consent of the Congress, lay any Imposts or Duties on Imports or Exports, except what may be absolutely necessary for executing it's inspection laws ...." Ibid. This provision and the commerce clause were assumed by the Supreme Court of Nevada and by counsel for Nevada to be the sole bases of decision. Id. at 40-41. See 2 Warren, The Supreme Court IN United States History 415 (Rev, ed. 1926).

131314 U.S. at 177 .

132 Id. at 179.

133 Ibid.

134179 U.S. 270 (1900). See Feinberg 29, quoting Joseph v. Randolph, 71 Ala. 499, 508 (1882), to the effect that the tax in Williams restrained "personal mobility, its 'obvious purpose ... [being] to seriously clog and impair the laborer's right of free emigration." " This view is supported by Georgia's failure to tax the hiring of workers to labor within the State, a discrimination challenged on equal protection grounds in Williams, with the Court doing an extremely poor job of explaining its rejection of this contention. 179 U.S. at 275-76. The Court did note that many other occupations were taxed, id. at 275 , but failed to see that some of these taxes, at least, were prohibitive. See $i b i d$. 
state, the Court rejected a commerce clause argument on the ground that the agents' activities were not sufficiently related to commerce. This case is not troublesome for the present analysis because this limited view of commerce is not tenable after Wickard $v$. Filburn. ${ }^{135}$ Indeed, Williams viewed in this light, supports protection of freedom of movement since the Court stated: "Undoubtedly the right of locomotion, the right to remove from one place to another according to inclination, is an attribute of personal liberty, and the right, ordinarily, of free transit from or through the territory of any State is a right secured by the Fourteenth Amendment and by other provisions of the Constitution."130

(c) Miln, Henderson and The Passenger Cases.-The opinions of the United States Supreme Court in City of New York v. Miln, ${ }^{187}$ The Passenger Cases, ${ }^{138}$ and Henderson v. Mayor of New York, ${ }^{130}$ between 1837 and 1875, show the development of the concept of the commerce clause as a bar to state action regulating in-migration, ${ }^{140}$ and, therefore, are precursors of Edwards.

In Miln, the majority upheld a New York statute requiring masters of vessels to report to the Mayor of New York City the name, birth place, last legal settlement, occupation, and age of all passengers disembarking there from any foreign country or other state of the United States. The Court held that the statute was a regulation under the police power and not of commerce. Justice Story, dissenting, ${ }^{141}$ disagreed, noting that the late Chief Justice Marshall lad taken the same position on an earher hearing of the case. ${ }^{142}$

In The Passenger Cases, while the Court split 5-4 and required eight opinions, it does seem clear that the majority held that state taxes on

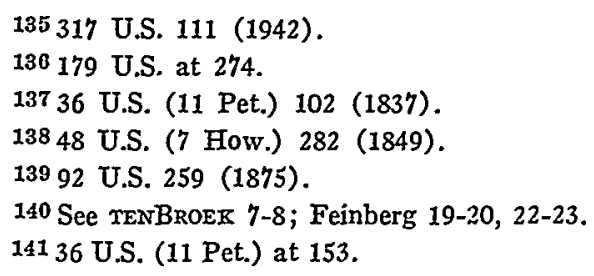

142 Id. at 160. As is noted in Lockeart, Kamasar \& Choper, Constitutionat Law 298 (1964), "Story's reference is to an earlier argument of the same case in 1834, when two justices who would have concurred with Marshall and Story were absent. Rather than to let a minority of the Court uphold the New York Act by a 3 to 2 vote, Chief Justice Marshall announced for the Court the previously unknown 'practice ... not (except in cases of absolute necessity) to deliver any judgment in cases where constitutional questions are involved, unless four justices concur in opinion, thus anaking the decision that of a majority of the whole court.' [33 U.S. (8 Pet.) 118, 121 (1834)] The Court ordered reargument. . . At the reargument only Story remained of the 4 who would have voted against the New York Act in 1834." 
passengers arriving from foreign ports were invalid under the commerce clause. ${ }^{143}$

The law was clarified further in Henderson v. New York, where a unanimous Court held unconstitutional, on commerce clause grounds, a New York statute requiring the owner or consignee of a vessel to supply a three hundred dollar bond for each alien passenger landed, to indemmify the state for any rehef needed by the passenger, or, in lieu of the bond, the owner or consignee to pay $\$ 1.50$ for eacl such passenger. Failure to supply the bond or pay $\$ 1.50$ made the carrier liable for a 500 dollar fine which was a lien on the ship. ${ }^{144}$

While these cases dealt mainly with foreign commerce, perhaps their greatest significance for present purposes is the dictum of Chief Justice Taney, dissenting in The Passenger Cases, ${ }^{145}$ quoted by the Court in Crandall:

Living as we do under a common government, charged with the great concerns of the whole Union, every citizen of the United States . . . is entitled to free access, not only to the principal departinents established at Washington, but also to its judicial tribunals and public offices in every State. ... We are all citizens of the United States, and as members of the same community must have the right to pass and repass through every part of it without interruption as freely as in our own States. ${ }^{140}$

(d) Can Edresards and Crandall Be Distinguished?-It may be objected that the assistance residence test case differs from Edwards, which involved a criminal penalty for helping certain persons move interstate, and Crandall, which taxed interstate travel. Residence tests for welfare assistance are not intended-at least prinarily-as a regulation of commerce or of personal travel. The main purpose is protection of the

143 See Henderson v. Mayor of New York, 92 U.S. at 266-67, so interpreting The Passenger Cases. For the details of the statutes invalidated, see 48 U.S. (7 How.) at 283-86. See generally 2 WARReN, THE SUPREMIE CoURT IN UNITEd States History 168-82 (Rev. ed. 1926).

14492 U.S. at 261. In a companion case, Cliy Lung v. Freeman, 92 U.S. 275 (1875), the Court invalidated, as infringing congressional control of foreign commerce, a California statute requiring ship captains to post bonds before certain classes of alien passengers may be landed, those classes including paupers and lewd women. The plaintiff was alleged to be in the latter cateory. As an alternative to posting bond, the captain could pay whatever sum of money the state's Commissioner of Immigration "may in each case think proper to exact." Id. at 278. The Court found that this statute amounted to legalizing extortion. Ibid. Since it went far beyond any enactment necessary and proper to protect the state from paupers and convicted criminals, the Court was "not called upon" to determine the constitutionality of legislation so suited for that purpose. Id. at 280 . This case is discussed in TENBROER 8.

14548 U.S. (7 How.) at 491-92, quoted in Feinberg 19.

14073 U.S. (6 Wall.) at $48-49$. 
state treasury. ${ }^{147}$ Because this was the motivation for the statute invalidated in Edwards, this "purpose" will not distinguish that case. Furthermore, the "protecting the public purse" argument is usually phrased as protecting it against newcomers, ${ }^{148}$ thereby indicating a clear "purpose" to discriminate against then.

Any argument that residence tests might be intended to bar newcomers from assistance until (1) they have been in a state long enough to contribute to its economy and hence the tax base from which the state funds such assistance, or (2) they have exhausted the possibilities of aid from private charity, ignores the fact that time spent in a state and therefore residence tests are unrelated to either goal.

The only arguably valid purposes that a state might claim for residence tests are (1) to prevent an influx of the poor whose sole or primary motive in migrating was to obtain higher assistance benefits than those for which they were elgible in their former home state, and (2) to furnish a means of determining bona fide residence. As will be explained later, means less restrictive of freedom of movement and less discriminatory against newcomers exist for dealing with these objectives. ${ }^{140}$ Therefore, they slould not be held to be capable of supporting the validity of residence tests.

An attempt to distinguish $E$ dwards as involving a criminal statute should fail for two reasons: (1) the effect on commerce of a fine or short jail term for a person knowingly assisting an indigent to enter a state would seem to be no greater than the effect on movement of residence tests denying poor newcomers the necessities of life; and (2) the Edwards holding has been applied to invalidate civil statutes. A recent decision by the widely respected Judge Justine Polier of the New York Family Court, In re Higgins, ${ }^{150}$ held that under the rationale of either the majority or concurring opinions in Edreards, certain demands made by Michigan in connection with placement of a child there were unconstitutional. ${ }^{\mathbf{1 5 1}}$

147 E.g., N.Y. Times, April 30, 1965, p. 1, col. 3 (reporting recommendations of New York State Committee on Welfare Costs); N.Y. Herald Tribune, Sept. 28, 1965, p. 11, col. 1 (report that local official will ask county board to request passage of residence test); see, e.g., LoGatto 105-06.

148 See note 147 supra.

149 See infra subsection $I, E, 5$.

15046 Misc. 2d 233, 259 N.Y.S.2d 874 (Family Ct. 1965), also reported in the New York 'Law Journal, May 20, 1965, p. 17, col. 5, as Matter of Anonymous (The Little Ivy case). 151 The child had been adjudged neglected by the New York Family Court, which discharged her into the custody of a maternal aunt living in Michigan. The Michigan Department of Social Welfare, as a condition for approving the placement, asked the New York court to sign an interstate agreement or a statement of the court retaining legal hability for the child. In other words, Michigan wanted New York to agree to reimburse Michigan for any future welfare expenditures for this child, who was not now receiving welfare. Judge 
In Anderson v. Mullaney, ${ }^{152}$ discussed in the next subsection of this article, the Ninth Circuit, in invalidating a license fee discriminating against nonresident commercial fishermen, treated the statute under attack as civil, although there seem to liave been criminal penalties for fishing without the required license. ${ }^{153}$

Next it may be argued that residence tests do not purport to bar interstate travel; they merely impede it. But for persons unable to live without public assistance for the required period, a residence test does bar interstate movement. If this is merely inpeding travel, the tax in Crandall merely impeded travel for persons unable to pay it. Furthermore, Justices Douglas and Goldberg, concurring in Bell v. Maryland, ${ }^{154}$ indicated that state action is unconstitutional even if it merely hinders interstate moveinent. Douglas, with the concurrence of Goldberg, viewed a state trespass conviction for refusal to obey a racially motivated request to leave a public accommodation, as invalid state action infringing the right to travel. ${ }^{155}$

Is the right of a person to eat less basic than his right to travel, which we protected in Edwards v. California . . . ? Does not a right to travel in modern times shrink in value materially when there is no accompanying right to eat in public places?

The right of any person to travel interstate irrespective of race, creed, or color is protected by the Constitution. Edwards v. California, supra. Certaimly his right to eat at public restaurants is as important in

Polier's decision invalidated the Michigan statute (MICH. Cosp. LAws $\$ 400.14$ (d) (1948)) which required sucl a guaranty before the Welfare Department could approve placement in Michigan of an out-of-state child. The decision also seems to imply the unconstitutionality of the New York statute, N.Y. Soc. WeLFARE LAW § 374-a (1960) (enacting the Interstate Compact on the Placement of Children), and administrative practice, see 46 Misc. $2 \mathrm{~d}$ at 234, 259 N.Y.S.2d at 875, under which a child will not be sent to another state unless the latter consents, at least where refusal of consent is predicated on the child's poverty or that of the person with whom placement is proposed. In re Higgins is highly relevant to an analysis of residence tests since it applied the $E d w a r d s$ result to invalidate civil law requirements, whereas Edwards voided a criminal statute. Moreover, the statement by Judge Polier, that efforts to require the sending state to retain liability for future welfare needed by a child seriously delay and often prevent the best placement, id. at 240, 259 N.Y.S.2d at 881, indicates strong policy reasons for rejecting the concept of settlement and residence tests as inappropriate for our mobile society, at least in regard to child placement. It is submitted that the effects of residence tests for assistance, discussed in the present article, similarly indicate that such tests are anachronisms.

152191 F.2d 123 (9th Cir. 1951).

153 ALASEA COMT. LAwS ANN. \$ 16.05.720 (1962).

154378 U.S. 226, 242, 286 (1964); see Feinberg 24-25. The concurring opinion of Douglas, with Goldberg concurring in parts II-V thereof, begins at 378 U.S. at 242. The concurring opinion of Goldberg, with Douglas concurring in parts II-V thereof, begins in id. at 286. The opinion of the Court never reached the constitutional issues. Goldberg and Douglas would have done so, as would the three dissenting justices. Id. at 318 . Only Goldberg and Douglas used a right-to-travel analysis.

$155 I d$. at $247,250-51,255$. 
the modern setting as the right of mobility. In these times that right is, indeed, practically indispensable to travel either interstate or intrastate. ${ }^{156}$

Justice Goldberg, with the concurrence of Justice Douglas, in discussing the congressional history of the fourteenth amendment and related legislation, stated: "The recurrent references to the right 'to go and come at pleasure' as being 'among the natural rights of free men' reflect the common understanding that the concepts of liberty and citizenship embraced the right to freedom of movement, the effective right to travel freely."167 Edwards v. California is also authority for the invalidity of state legislation which merely hinders the right to travel. The offense there was knowingly bringing a nonresident into the state. ${ }^{158}$ By making such conduct a crime, Cahifornia in effect prevented others from knowingly assisting nonresident imdigents to cross the state hine.

An attempt to distinginish Crandall and Edwards with a necessity argument will also fail, because it is very unlikely that any state today could claim a greater threat to its welfare budget than that faced by California when it enacted the statute voided in Edwards.

A similar fate awaits any argument based upon the long history of residence tests and of the underlying concept of settlement. ${ }^{160}$ The legislation before the Court in Edwards could also claim the support of hoary antecedents and of the settlement concepts. ${ }^{100}$ The view of the poor as a "moral pestilence," the basis for much of the prior authority which might be cited in contending for the vahility of residence tests, was expressly rejected by the Court in Edwards. ${ }^{101}$ Finally, constitutional doctrine must grow to meet the requirements of a changing society and evolving concepts of human dignity and the needs which must be met to mamtain it. The United States becomes more one nation every year, with greater mobility of population. ${ }^{102}$ It seems fair to say that an

156 Id. at 255 .

157 Id. at 293 n.10, citing Cong. Globe, 39TH CoNg., 1st Sess., at 322, 41-43, 111, 475. Justice Black, writing on behalf of the three dissenters, disagrees with Goldberg's reading of some of his authority regarding the right of the colored man "to go where he pleases." Id. at 337 n.25.

158314 U.S. at 171.

150 See Mandelker, The Settlement Requirement in General Assistance; 1955 WaSH. U.L.Q. 355-58.

160 See 314 U.S. at 174; Mandelker, Exclusion and Removal Legislation; 1956 WIs. L. REv. 57, 59-60.

161314 U.S. at 177.

a02 See, e.g., Legislation Note, Voting Rights-Residence Requirements for Voting in Presidential Elections, 18 VAND. L. REv, 337 (1964): "In the 1960 presidential election, between five and eight million American citizens, otherwise qualified to vote, were disenfranchised by virtue of their having changed places of residence during the year preceding the election," citing Scammon, The Electoral Process, 27 LAw \& Contemp. Prob. 299, 304 
increasing awareness of human needs and of the obligation of government to meet them has developed and includes, in the minds of many Americans, a feeling that the poor should not be deterred from interstate migration. Indeed, the needs of the economy for a fluid supply of manpower will be best met if free interstate movement is available to those with hittle or no funds.

A more sophisticated argument would be that Edwards represents (1) a severe, direct burden on freedom of movement, and (2) a strong necessity for the legislation, and Crandall combined (1) a minor, indirect burden on this freedom, and (2) no necessity for the tax statute. The residence test situation combines the aspects of each case most favorable to upholding the legislation - a minor, mdirect burden on commerce and a strong necessity-and does not involve the unfavorable aspects which outbalanced these factors in Edwards and Crandall.

An answer to this argument may be made as follows: (1) Residence tests impose a severe burden on interstate movement, if severity is judged from the standpoimt of the relevant citizens, those without the financial ability to support themselves in a state for the period of residence required for welfare assistance. (2) If severity is judged by the number of people prevented from migrating, the extent of the benefit to the state (the necessity for the test) will vary directly with the burden on commerce. The reduction in welfare costs will be commensurate, to a large extent, with the number of people deterred from entering. Admittedly, there will be a saving in regard to each newcomer, but the brevity of the residence period indicates that this saving will not be great. The substantial economies arise when potential long-term welfare recipients are unable to enter. (3) Edwards lends no support to the contention that its holding was based upon a balancing of burden on commerce against necessity for the statute. The Court made it clear that a desire to exclude paupers was not a constitutionally cognizable justification for any state legislation. ${ }^{163}$ Similarly, the Court in Crandall did not stress the lack of any compelling reason for the state tax statute.

Also, it does not seem proper to distinguish Edvards and Crandall as involving a more direct interference with interstate movement than that imposed by assistance residence tests. The statute invalidated in Edrwards penalized the person who knowingly assisted the nonresident indigent to enter California. The tax in Crandall struck directly at the pocketbook of the migrant, but so do the residence tests. Moreover, losing eligibility

(1962). See also Schmidhauser, Residency Requirements for Voting and the Tensions of a Mobile Society, 61 Micr. L. Rev. 823, 824-30 (1963).

163314 U.S. at 176-77. 
for assistance probably is, to an indigent, a worse penalty than a threat of fine or imprisonment.

(e) Two Recent Federal Cases.-Two cases arising in Alaska lend strong support to a commerce clause analysis: One of them, through its alternative holding based upon the privileges and immunities clause of article IV, also aids that line of attack upon residence tests. In Anderson v. Mullaney, ${ }^{164}$ the Ninth Circuit, with one judge dissenting on other grounds, ${ }^{165}$ held that the portion of a license fee ${ }^{100}$ for nonresident fishermen-which exceeded the fee for resident fishermen was an unconstitutional burden on interstate commerce in commercial fishermen and void. This case was affirmed on other grounds by the United States Supreme Court. ${ }^{167}$ The Ninth Circuit noted the existence of an argument under the privileges and immunities clause of article IV, ${ }^{168}$ but found it unnecessary to reach that question. ${ }^{169}$ In Brown v. Anderson, ${ }^{170}$ a federal district court judge, in alternative holdings relying upon the commerce clause and article IV protection of privileges and immunities, held unconstitutional an Alaska statute ${ }^{171}$ authorizing the closing of certain fishing areas to nonresident fishermen while allowing residents to fish there.

Anderson v. Mullaney indicates the great strength of the commerce clause's guarantee of freedom of interstate movement, since the tax charged nonresidents was only fifty dollars, a inere forty-five dollars more than the five dollar tax on residents. ${ }^{172}$ Such a differential would seem to be inuch less of a hindrance to interstate travel than are the residence tests for welfare assistance programs. Alaska was a territory in 1951, but the Ninth Circuit held that the same rules applied to commerce from and to a territory as governed interstate commerce. ${ }^{173}$

164191 F.2d 123 (9th Cir. 1951), aff'd on other grounds, 342 U.S. 415 (1952).

105 Id. at 134. Part (B) of the dissenting opinion of Chief Judge Denman may be read as rebutting part of the majority's commerce clause argument. In Part (B), he argues that plaintiffs failed to carry their burden of proving that the license fee for nonresidence is arbitrary or excessive.

166 Alaska Sess. Laws 1949, ch. 66.

167 Sub nom. Mullaney v. Anderson, 342 U.S. 415 (1952).

168191 F.2d at 126.

169 Id. at 133 .

170202 F. Supp. 96 (D. Alaska 1962).

${ }^{171}$ Alaska Sess. Laws 1961, ch. 62 . This provision has been deleted from the Alaska statutes.

172191 F.2d at 125.

173 Id. at 127. The Ninth Circuit cited as authority its prior decision in Inter-Island Steam Nav. Co. v. Territory of Hawaii, 96 F.2d 412, 416, 417 (9th Cir.), aff'd on otther grounds, 305 U.S. 306 (1938), and the following cases in which the Ninth Circuit said the cited proposition "has been assumed to be true": McLean \& Co. v. Denver \& Rio Grande R.R. Co., 203 U.S. 38, 49 (1906) ; Hanley v. Kansas City Southern Ry. Co., 187 U.S. 617, 620 (1903) ; Inter-Island Steam Nav. Co. v. Territory of Hawaii, 305 U.S. 306, 313 (1938) 
Brown is especially pertinent to an examination of residence tests for assistance, since the argument was made and rejected there that the state statute condemned was necessary to protect the citizens of Alaska against the costs of caring for the indigent. ${ }^{174}$ Discussion of this holding will be deferred, ${ }^{175}$ since the main thrust of the opinion was directed to the privileges and immunities issue.

(f) The Power of Congress.-A commerce clause analysis is vulnerable: if the unconstitutionality of residence tests is based upon the exclusive power of Congress to regulate such commerce, Congress could override this objection with an enabling statute. The widespread use of residence tests in many states, ${ }^{176}$ and the recurrent requests to enact them in others, ${ }^{177}$ indicate that considerable pressure would be put on Congress to undercut any Supreme Court decision invalidating residence tests under the commerce clause.

That Congress is not necessarily opposed to residence tests for assistance programs may be indicated by the conditions set by the Social Security Act for state categorical assistance plans qualifying for federal financial participation. Congress expressly states that plans which meet the other criteria qualify if their residence requirements are within the parameters set forth.

(g) Has Congress Acted?-Even if it be concluded that, in the absence of contrary congressional intent, the states may not impose residence requirements affecting interstate movement of persons, the congressional approval of limited tests for categorical assistance may be interpreted as an implicit indication that Congress is not opposed to residence tests for other state public benefit programs, and especially not for general assistance programs, which aid needy persons who do not qualify for federally-aided assistance and federal insurance programs. A strong argument can be made that (1) it would be anomalous for Congress to have a different policy for different assistance programs, (2) it would be especially anomalous for Congress to give the states less freedom in setting standards for programs entirely state-funded than for those partially federally-financed, and (3) any such distinctions of policy would run afoul of the equal protection guarantee implicit in fifth amendment due process. ${ }^{178} \mathrm{~A}$ subsidiary question which would arise if

174202 F. Supp. at 101-02.

175 See infra subsection II, $D, 3, a$.

170 See National Travelers aid Ass's, One Manner of LaW-A Handbook on Residence Requiremients in Public Assistance 8-13 (1961).

177 See, e.g., N.Y. Times, April 30, 1965, p. 1, col. 3 (a report of the recommendations of the New York State Committee on Welfare Costs); N.Y. Herald Tribune, Sept. 28, 1965, p. 11, col. 1 (Supervisor of Riverhead, L.I., will ask county board to request passage of residence test).

178 See infra subsection III, $B$. 
this analysis is accepted, is whether or not the implicit congressional approval extends only to public assistance residence tests wlich are within the himits set in the Social Security Act for categorical assistance.

However, the foregoing analysis would attribute to Congress an intent far exceeding that which was present in the legislators' minds when they approved limited residence tests for categorical assistance. ${ }^{170}$ Freedom of interstate movement is an aspect of commerce involving such important human rights that Congress should be required to legislate exphicitly in regard to residence tests for assistance, in order to regulate that commerce.

Nevertheless, the possibihty of a contrary decision, and the power of Congress to act expressly, makes the commerce clause something less than an ideal road to the abolition of residence tests for public assistance. (h) The Rights of Nonresidents. - The constitutional guarantee of freedom of movement, under the commerce clause or otherwise, may require a state to extend its assistance programs to nonresidents. Persons presently receiving assistance in their home state will be deterred from traveling to and through other states if they may thereby risk termination of assistance from their old home state, without qualifying for assistance in states they visit. Even if inconsistent determinations as to residence are avoided, travel is discouraged unless the traveler can be assured of assistance in the state where he needs it.

The situation of the migratory worker ${ }^{180}$ is probably the most striking example of the effect on freedom of movement of residence tests for assistance. Mobility of the labor force, including seasonal workers, promotes the efficiency of economic enterprises and therefore the growth of the gross national product. ${ }^{181}$ In situations like that of the migratory farm worker, who may not intend to become a citizen of any state he enters while following the harvests, residence tests for welfare diminish his freedom to move in search of this work. In the event of family tragedy, inability to find the work anticipated, or some other difficulty, he and his family will not be eligible for welfare benefits. The worker's willinguess to take these risks will be reduced. However, this view must

179 Indeed, when the Social Security Act was passed in 1935, Edwards had not been decided, and in all probability the members of Congress allowed residence tests largely because they were a traditional part of assistance programs. It may well be that the traditional trappings were useful to coat the bitter pill of assistance which was partially federally financed, a deviation from prior practice.

180 See e.g., Wright, They Harvest DespaIR (1965); The Comm. of Labor and Social Security Legislation, The Ass'n of the Bar of the City of New York, Migratory Labor, Reports of Committees of The Association of the Bar Concerned with Federal Legislation, June, 1965, p. 108; Feinberg 40; Givens, Legal Disadvantages of Migratory Workers, 16 LAB. L.J. 584 (1965).

181 See Nathanson 17-18. 
contend with the apparent reasonableness of discriminations based on state citizenship, in regard to state programs. The more humane policy of requiring assistance to be offered on an equal basis to nonresidents will also raise worries about welfare recipients who winter in Florida and summer on Cape Cod. Arguably, an adequate answer is the low rate of assistance payments, making such a life unattractive.

It seems fair to conclude that the unconstitutionality of a requirement of residence is less clear than that of a required period of residence. In light of the equal protection guarantee, wlicli extends to all persons subject to a state's jurisdiction, and the importance of freedom of movement, the better result is to lold invalid the restriction of assistance to residents.

(i) Possible Difficulties with an "Interference with Freedom of Movement" Analysis.-Before two other constitutional provisions that may protect freedom of interstate movement are examined, it may be best to consider-in this subsection and in the one that follows-certain objections to a freedom of movement analysis that may be troubling the reader, although these arguments are applicable whether that freedom is regarded as protected under the commerce clause or some other constitutional provision.

One possible argument in opposition to an interference with freedom of movement analysis is as follows: If a state is to be forbidden to enact welfare legislation restricting or discouraging interstate freedom of nnovement, the logic of sucl a rule would also require a state to provide benefits equivalent in buying power, and so conditioned as to be comparable, to those available in other states. Each state will be forced to matcl, in buying power, the benefits available in the most generous state. Otherwise, potential migrants from that state might be deterred. But sucl an approach contravenes the well-settled rule that no state is constitutionally required to have welfare programs. ${ }^{182}$ Rights which may accrue under established programs are far different from notions of a general riglt to the creation of welfare programs. There will be the greatest hindrance to free movement when no welfare program exists in a state while other states have such programs. These anomalies suggest that the constitutionality of assistance programs should not be evaluated in terms of interference with interstate freedom of movement.

This argument overlooks the need to weigh all of the following factors in evaluating the constitutionality of residence tests and of a state's failure to liave certain welfare programs: (i) the effect on freedom of interstate movement; (ii) the purpose belind the state legislation or

182 E.g., People ex rel. Heydenreich v. Lyons, 374 Ill. 557, 565, 30 N.E.2d 46, 51 (1940). 
lack thereof; (iii) the state's interest in pursuing its policy; (iv) the proximate cause of the effect on migration; and (v) the distinction between state action and inaction.

(i) Effect.-While a state's failure to have a particular welfare program may be a greater deterrent to in-migration than a residence test for that program, especially if the required residence period is relatively short, the impact of a state's policy against having a program is not confined to newcomers. Therefore, that policy avoids the discriminatory aspect which permeates residence tests. Discrimination against newcomers not only is an effect which may be indicative of the state's purpose, but also provides a way to delineate the areas where the courts may apply constitutional protection for freedom of movement, without logically having to undertake supervision of all aspects of state policymaking influencing in-migration. If the courts will invalidate the failure of a state to have certain welfare programs, the same analysis would require thein to also hold unconstitutional state minimum wage, education, taxation, and all other pohicies whicl may influence the decision of persons to move to that state. Therefore, discrimination against the newcomer should be viewed as the crucial effect under the commerce clause analysis, as well as in regard to other grounds for invalidating assistance residence tests. ${ }^{183}$

(ii) Purpose.-A state may choose not to create welfare programs for reasons totally unrelated to any intent to deter or penalize ingress of persons from other states. Similarly, a state may decide not to match the benefits or hberal conditions of other states' welfare benefits. On the other hand, an intent to discriminate against newcomers, although phrased more politely, is frequently expressed as the reason for enactment of assistance residence tests. ${ }^{184}$ And even in the absence of an express statement of intent, it is difficult to envision any nondiscriminatory state interest served by sucli tests or any arguably valid discriminatory state interest so served which could not be satisfied by a statute less restrictive of individual riglits. ${ }^{185}$

(iii) State's Interest.-A state's interest in being allowed to choose not to lave a particular assistance program is greater than its interest in having a residence test for that program upheld, because the expenditures avoided by the former policy are much larger.

(iv) Proximate Cause.-A strong argument may be made, as will be shown shortly, ${ }^{186}$ that the residence test of the actual or potential new

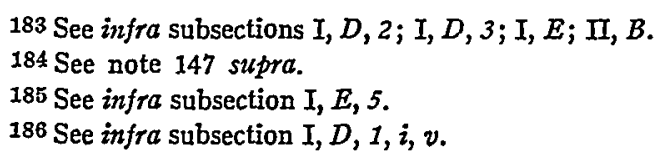


state of abode, rather than. the existence of an assistance program in the state from which the migrant will move (and the refusal of that state to continue assistance after he leaves), is the cause of any infringement of freedom of movement. Causation is less clear when the lack of an assistance program in the new home state is compared with the existence of such a program in the former home state. The pohicy of one state against having an assistance program would not deter movement if the former home state did not have a program. Also, the decision not to have a program, hike the decision to enact one, is unlikely to have been inotivated by a desire to deter or penalize migration.

(v) State Action and Inaction.-When a state acts affirmatively, it may be easier to attribute a purpose, than when the state does not act. There are many explanations for state inaction that are unrelated to an intent to interfere with interstate movement. It would be extremely difficult for a court to ascertain these reasons, and an attempt to do so would lead judges into examinations of the bases for all sorts of programs or the lack thereof. It seems fair to say that when a state acts affirmatively, it gives more consideration to effects and purposes than when a state does not act - and that therefore a higher standard should be apphed to action than to inaction in weighing various other factors to ascertain constitutionality.

Consideration of the five factors just discussed indicates that there would be nothing illogical im holding assistance residence tests unconstitutional although at present the law is well-settled that a state is not required to have welfare programs. A similar argument will dispose of the corollary contention that it would be anomalous to invalidate residence tests but not require a state with an assistance program to match in benefits the buying power of assistance benefits available in the state from which a migrant moves.

Another possible objection to a freedom of movement analysis is that the existence of an assistance program in the potential migrant's present state of residence, and the refusal of that state to continue assistance after the migrant moves to another state, is as much the cause of inhibiting interstate movement as is the residence test in the contemplated new state of residence.

However, the old lome state (1) did not enact an assistance program with the purpose of deterring interstate movement, and (2) is treating all of its citizens alike, since state citizenship is governed by residence, under the fourteenth amendment. The state with the residence test (1) probably enacted it with a purpose of deterring interstate movement, and (2) is treating certain state citizens unequally. Therefore, the residence test, rather than the old home state's assistance program, must 
be the legislation evaluated in terms of infringing freedom of movement. (j) Must a State Encourage and Reward Interstate Movement? - If it is agreed that a state may not penalize interstate movement, does it follow that such movement must be encouraged and rewarded? Where a state's assistance benefits are greater in purchasing power than those available in the state from which a potential migrant considers moving, he may be encouraged to move. May his new state of residence reduce the benefits for which he is ehigible to the equivalent of those available in his former state? Under a freedom of movement analysis, the answer would seem to be in the affirmative. However, as will be discussed in subsection $\mathrm{I}, \mathrm{E}$ of this article, providing lower assistance payments to some newcomers would seem to contravene the state citizenship and equal protection clauses of the fourteenth amendment.

\section{The Privileges and Immunities Clause of the Fourteenth Amendment}

The fourteenth amendment reads, in relevant part: "No State shall make or enforce any law which shall abridge the privileges or immunities of citizens of the United States ...."

(a) The Concurring Opinions in Edwards.-The leading authority supporting the protection of a freedom of interstate movement under the privileges and immunities clause of the fourteenth amendment is the concurring opinion of Justice Douglas in Edwards v. California. ${ }^{187} \mathrm{He}$ declared: "The right to move freely from State to State is an incident of national citizenship protected by the privileges and immunities clause of the Fourteenth Amendment against state interference."188 Douglas, joined by Black and Murphy, argued that Crandall v. Nevada ${ }^{180}$ held that "the right to move freely from State to State was a right of national citizenship." ${ }^{190}$ This right was then protected against state interference by the privileges and immunities clause when the fourteenth amendment was adopted, under the doctrine laid down in the Slaughter-House Cases. ${ }^{101}$ There the Court gave as its first example of a right protected under that clause-that is, of those privileges and immunities "which owe their existence to the Federal government, its National character, its Constitution, or its laws"192 - the right to come to the seat of government and the seaports, and cited Crandall as authority. ${ }^{193}$

187314 U.S. 160, 177 (1941).

$188 \mathrm{Id}$. at 178.

18973 U.S. (6 Wall.) 35 (1867).

100314 U.S. at 179.

19183 U.S. (16 Wall.) 36 (1873). Douglas's argument appears in 314 U.S. at 179.

102 Id. at 79 (cited in Feinberg 20); see Hague v. C.I.O., 307 U.S. 496, 520-21 n.1, 526

(1939) (concurring opimion of Stone, J.).

10383 U.S. (16 Wall.) at 79. 
Since Douglas' argument hinges upon his reading of Crandall, a not unambiguous opinion, it might be thought fairly weak authority. However, there seems no doubt that even without Crandall, Douglas would regard freedom of interstate inovement as a privilege and immunity of national citizenship.

Justice Douglas found further support for his interpretation of the privileges and immunities clause of the fourteenth amendment in Corfield $v$. Coryell, ${ }^{104}$ a case construing the privileges and immunities clause of article IV and decided on circuit by Justice Washington in 1823. While his view of that clause as protecting "natural rights" has been rejected, ${ }^{195}$ Justice Washington's words are iniportant as an early recognition of freedom of interstate movement:

The inquiry is, what are the privileges and immunities of citizens in the several states? We feel no hesitation in confining these expressions to those privileges and immunities which are, in their nature, fundamental; which belong, of right, to the citizens of all free governments; and which have, at all times, been enjoyed by the citizens of the several states which compose this Union, from the time of their becoming free, independent, and sovereign. . . . The right of a citizen of one state to pass through, or to reside in any other state, for purposes of trade, agriculture, professional pursuits, or otherwise; . . . may be mentioned as [one] . . . of the particular privileges and immunities of citizens, which [is] . . . clearly embraced by the general description of privileges deemed to be fundamental . . . 196

If Douglas' view of the privileges and immunities clause is accepted, his words seen particularly pertinent to a consideration of the validity of residence requirements for welfare assistance in light of the effect of such tests on interstate movenient:

If a state tax on that movement, as in the Crandall case, is invalid, a fortiori a state statute which obstructs or in substance prevents that movement must fall. That result necessarily follows unless perchance a State can curtail the right of free movement of those who are poor or destitute. But to allow such an exception to be engrafted on the rights of national citizenship would be to contravene every conception of national umity. It would also introduce a caste system utterly incompatible with the spirit of our system of government. It would permit those who were stigmatized by a State as indigents, paupers, or vagabonds to be relegated to an inferior class of citizenship. It would prevent a citizen because he was poor from seeking new horizons in other States. It might thus withhold from large segments of our people that mobility which is basic to any guarantee of freedom of opportunity. The result 
would be a substantial dilution of the rights of national citizenship, a serious impairment of the principles of equality. ${ }^{107}$

Justice Douglas' argument is strongly supported by dictum in Twining $v$. New Jersey ${ }^{198}$ in 1908 , in an opinion for eight justices including Justice Holmes. The Court stated that the privileges and immunities of United States citizens, protected by the fourteenth amendment, "are only such as arise out of the nature and essential character of the National Government, or are specifically granted or secured to all citizens or persons by the Constitution of the United States" and "among the rights and privileges of National citizenship recognized by this court are the right to pass freely from State to State, Crandall v. Nevada . . ." "100

This authority is undercut by language, again of eight justices, in United States $v$. Wheeler. ${ }^{200}$ In this case involving private action to deport United States citizens from a state, the Court found

that the case of Crandall v. Nevada, ... is inapplicable, not only because it involved the validity of state action, but because the state statute considered in that case was held to directly burden the performance by the United States of its governmental functions and also to limit rights of the citizens growing out of such functions; and hence it also follows that the observation made in Twining $v$. New Jersey... to the effect that it had been held in the Crandall Case that the privilege of passing from State to State is an attribute of national citizenship, may here be put out of view as inapposite.

With the object of confining our decision to the case before us, we say that nothing we have stated must be considered as implying a want of power in the United States to restrain acts which, although involving ingress or egress into or from a State, have for their direct and necessary effect an interference with the performance of duties which it is nicumbent upon the United States to discharge, as illustrated in the Crandall Case, supra. ${ }^{201}$

However, Douglas, in Edwards, ${ }^{202}$ argued that in Wheeler the Court was in error in its analysis of Crandall. He acknowledges that Justice Miller "emphasized that the Nevada statute would obstruct the right of a citizen to travel to the seat of his national government or its offices throughout the country." 203 Douglas then states:

But there is not a shred of evidence nil the record of the Crandall case

197314 U.S. at 181.

198211 U.S. 78 (1908).

199 Id. at 97 . The dissenting opinion of Justice Harlan, id. at 114, expressly declined to list the privileges and immumities protected by the fourteenth amendment. $I d$. at 123 .

200254 U.S. 281 (1920) (8-1 decision, Justice Clarke dissenting without opinion).

201 Id. at $299-300$.

202314 U.S. at $178-79$.

203 Id. at 178 . 
that the persons there involved were en route on any such mission .... The point which Mr. Justice Miller made was merely in illustration of the damage and havoc which would ensue if the States had the power to prevent the free movement of citizens from one State to another. This is emphasized by his quotation from Chief Justice Taney's dissenting opinion in the Passenger Cases . . . "We are all citizens of the United States; and, as members of the same community, must have the right to pass and repass through every part of it without interruption, as freely as in our own States."204

Therefore, Douglas concludes that the Wheeler opinion erred in limiting Crandall "to a holding that the statute in question directly burdened 'the perfornance by the United States of its governmental functions' and limited the 'rights of the citizens growing out of such functions.' "'205

Douglas could also have supported his reading of Crandall by noting that Justice Miller's reasons for his lolding extended beyond (1) the right of the government to call citizens to the capital city, to secondary centers of government, to ports of entry, and to land offices, revenue offices, and subtreasuries, and (2) the right of the citizen to access to all these governmental locations. ${ }^{206}$ Justice Miller also stated that a United States citizen "has a right to free access to its sea-ports, through which all the operations of foreign trade and commerce are conducted."207 Moreover, the quotation from Chief Justice Taney includes the following language: "And a tax imposed by a State, for entering its territories or harbors, is inconsistent with the rights which belong to citizens of other States as members of the Union, and with the objects which that Umion was intended to attain.' "208 It would seem that Crandall reflects the view that one of the objects of the Union was to protect freedom of interstate movement.

Justice Jackson's concurring opinion in Edwards ${ }^{209}$ stressed the relationship between the clauses of the fourteenth amendment which (1) define United States citizenship, and (2) forbid any state to abridge the privileges or immunities of Umited States citizens. He would have held

that it is a privilege of citizenship of the United States, protected from state abridgment, to enter any state of the Union ... for gaming resultant citizenship thereof. . . .

. . . State citizenship is ephemeral. It results only from residence

$204 I d$, at $178-79$.

205 Id. at 179.

20673 U.S. (6 Wall.) $35,43-44$ (1867).

207 Id. at 44 .

208 Id. at 49, quoting The Passenger Cases, 48 U.S. (7 How.) 283, 492 (1849) (dissenting opinion).

200314 U.S. at 181. 
and is gained or lost therewith. That choice of residence was subject to local approval is contrary to the inescapable implications of the westward movement of our civilization. ${ }^{210}$

Jackson noted that freedom of interstate movement is not unlimited, but that "indigence" is not a valid reason for restricting such movement. ${ }^{211}$ "[A] man's mere property status, without more, cannot be used by a state to test, qualify, or limit his rights as a citizen of the United States. 'Indigence' in itself is neither a source of riglits nor a basis for denying them. The mere state of being without funds is a neutral fact-constitutionally an irrelevance, hike race, creed, or color."212

(b) Kent, Aptheker, Zemel and Guest.-The importance of the constitutional right to free movement interstate has been reiterated by the Supreme Court in three cases dealing with freedom of international travel: Kent v. Dulles, ${ }^{213}$ Aptheker v. Secretary of State, ${ }^{214}$ and Zemel v. $R u s k_{.}^{215}$ While these statements are not explicit as to the constitutional basis for freedom of interstate movement, the citation of $E d w a r d s$ in these cases $^{216}$ indicates the Court would base its protection against state action either on the commerce clause or the privileges and immunities clause of the fourteenth amendment. These cases will be discussed at length in the portion of this article dealing with residence tests for categorical assistance. ${ }^{217}$

The Supreme Court, on March 28, 1966, in some of the opinions in United States v. Guest, ${ }^{218}$ again noted the importance of the constitution-

210 Id. at 183 .

211 Id. at 184-85.

212 Ibid.

213357 U.S. $116,125-27$ (1958).

214378 U.S. 500, 505-06 (1964).

215381 U.S. 1, 14-16 (majority opinion), 23-24 (dissenting opinion of Douglas and Goldberg, JJ.) (1965).

216357 U.S. at 126; 381 U.S. at 15. In Aptheker, Douglas concurred, cited Edwards, and repeated his view in that case that freedom of movement interstate should be based on the privileges and imnunities clause of the fourteenth amendment. 378 U.S. at 519.

217 See infra subsection III, $A$.

21886 Sup. Ct. 1170 (1966). The right to travel is discussed in id. at 1177-79 (opinion of the Court by Stewart, J.); (opinion of Harlan, J., concurring in part and dissenting in part); 1183 n.3 (opinion of Justice Brennan, J., Warren, C.J., and Douglas, J., concurring in part and dissenting in part). The latter opinion does not cite any constitutional provision as the basis for the right to travel. Justice Stewart mentions various cases and bases discussed in the present article, $i d$. at 1178, finds it unnecessary to determine the basis or bases, id. at 1179, and says there is no doubt that the nine justices "all have agreed that the right exists." Ibid. Justice Harlan notes several bases for the right, id. at 1181-85, including the due process clauses of the fifth and fourteenth amendments, which were recommended, although without much supporting analysis, by Professor Chafee, in THREe Human RIGHTS IN THE ConstituTION of 1787, at 192-93 (1956). The present article does not discuss the due process clause of the fourteenth amendment as a basis for protecting freedon of travel, since the relevant problem-at least in regard to residence tests-seems to be iniproper classification, and therefore is best analyzed under the equal protection clause. See generally Tussman \& tenBroek, 
ally-protected right to travel. The high priority given this right, and its wide-ranging impact was stressed earlier in the dissenting opinions of Justices Black and Douglas in New York v. O'Neill ${ }^{219}$ and Wiltiams v. North Carolina. ${ }^{220}$

The Equal Protection of the Lazes, 37 CaIIF. L. Rev. 341 (1949). For the same reason, the present article discusses the equal protection guarantee incorporated in the due process clause of the fifth amendment, rather than the due process aspect thereof.

219359 U.S. 1 (1959); see Feinberg 19, 26-28. In this case, seven justices, in an opinion by Justice Frankfurter, held that the Uniform Law to Secure the Attendance of Witnesses from Within or Without a State in Criminal Proceedings, FLA. STaT., \$§ 942.01-.06 (1963), under which a witness in a state could be ordered by a court therein to go or be sent in custody to another state to testify in a criminal proceeding, did not violate the privileges and immunities clause of the fourteenth amendment. Frankfurter argued that even if under that clause "broad scope" were given to the right of "ingress and egress" across state lines, (1) the Uniform Act limits the right no more than does the admitted power of the ordering state to hold the witness for appearance in its own criminal proceedings, 359 U.S. at 7 ; (2) "the obligation to give testimony" is a restriction on the claimed right, ibid.; (3) "at most" there is only "a temporary interference with voluntary travel," ibid.; and (4) the policy behind the right is consistent with the aims of the Uniform Act: "The privilege of ingress and egress among the States ... was to prevent the walling off of States, what has been called the Balkanization of the Nation. The requirement which respondent resists conduces . . . toward a free-willed collaboration of independent states." Id. at 7-8.

Douglas and Black, in dissent, id. at 12, would have held that freedom of interstate movement, whether based on the fourteentl amendment privileges and immunities clause, on the commerce clause, or on a basic liberty inherent in national citizenship, is limited by the extradition clause of the Constitution, art. IV, $\S 2$, applicable to fugitives. They argued that the states have no authority to expand the extradition power. The Umiform Act allows "a State to pick a citizen up and forcibly remove him from its boundaries where there is no basis for extradition." 359 U.S. at 15. "To say that there is no interference here because O'Neill will be free to return to Florida later is to trifle with a basic liuman right." Id. at 16 . But Douglas did state: "This right of freedom of movement even of the innocent may not be absolute. Perhaps a State could stop a migrant at its borders for health imspection. There may be other narrow and limited qualifications to this right of free ingress and egress which a State may impose." Id. at 15.

220325 U.S. 226 (1945). In this second Supreme Court case involving the same prosecution, the majority had upheld a North Carolina conviction for bigamous cohabitation, against a man and woman who, domiciled in that state, had gone to Nevada and obtained divorces from their respective spouses, married each other, and returned to North Carohina. The majority held that domicile in a state is required for jurisdiction to grant a divorce decree and that the Nevada decree was subject to collateral attack on the ground that the parties were never domiciled in Nevada, even though the record of the Nevada proceedings purported to show jurisdiction. Black and Douglas, in dissent, id. at 261, argued that one consequence of the majority's holding "is to subject people to criminal prosecutions for adultery and bigamy merely because they exercise their constitutional right to pass from a state in which they were validly married into another state which refuses to recognize their marriage. Such a consequence runs counter to the basic guarantees of our federal union. Edwards $v$. California. ... It is true that persons validly married under the laws of one state have been convicted of crime for living together in other states. But those state convictions were not approved by this Court." Id. at 265. Black's citation of Edwards is to the majority opinion based upon the commerce clause, despite the fact that Black joined Douglas in arguing in Edwards for basing freedom of movement upon the privileges and immunities clause of the fourteenth amendment. Undoubtedly Black's view is that under either of the analyses in Edwards, such a freedom of movement exists. 
(c) Freedom of Interstate Movement and a Civil Rights March.The importance of the right to move freely interstate is underscored by a recent Alabama per curiam opinion holding the interest of the state, acting under its police power, in punishing "conduct calculated to provoke a breach of the peace," ally protected right. ${ }^{222}$ Especially important is the context in which this case, Hanson v. State, was decided by the Court of Appeals of Alabama: a march into Alabama in protest against the murder of a civil rights pilgrim, ${ }^{223}$ a march which the state alleged tended "to create racial tensions at a time when said racial tension was already high and the general public apprehensive of racial violence in this State."224 The governor of Alabama had requested that the march not be held.25

The Alabama court clearly based its decision on freedom of movement, probably relying upon the privileges and immunities clause of the fourteenth ainendment. However, the commerce clause might have been regarded as the source of the constitutional guarantee. ${ }^{22 B}$

221 ALA. Code ANs. tit. $14 \$ 119$ (1) (Supp. 1963) makes disturbing the peace "by . . conduct calculated to provoke a breach of the peace" a misdemeanor.

222 Hanson v. State, 42 Ala. App. 409, 166 So. 2d 886 (1964). This decision does not seem to have been appealed.

223 See Zellner v. Lingo, 218 F. Supp. 513, 514 (M.D. Ala. 1963), aff'd per curiam, 334 F.2d 620 (5th Cir. 1964).

22442 Ala. App. at 410,166 So. $2 d$ at 886.

225 Ibid.

226 The Court of Appeals of Alabama did not feel it was necessary to write a full opinion. The per curiam opinion merely set forth the complaint and held it failed to state an offense, citing the following five cases: Edwards v. California, 314 U.S. 160 (1941); Zellner v. Lingo, 218 F. Supp. 513 (M.D. Ala. 1963) [aff'd per curiam, 334 F.2d 620 (5th Cir. 1964)]; Opinion of the Justices, 275 Ala. 547, 156 So. 2d 639 (1963); Ex parte Lavinder, 88 W. Va. 713, 108 S.E. 428 (1921); Constantin v. Smith, 57 F.2d 227 (E.D. Tex.) [afj'd sub nom. Sterling v. Constantin, 287 U.S. 378 (1932)].

In Zellner, a federal district court judge, applying the doctrine that equity will not enjoin a criminal prosecution, refused to enjoin the prosecution of the appellants in Hanson. However, he probably influenced the decision of the Alabama Court of Appeals since he quoted at length from the concurring opinion of Mr. Justice Douglas in Edwards, $218 \mathrm{~F}$. Supp. at 515 , and expressly disclaimed any approval of the state's prosecution of defendants. Id. at 518 .

Since the federal court quoted Douglas's language relying upon the privileges and immunities clause of the fourteenth amendment, but purported to be quoting the opinion of the majority, see 218 F. Supp. at 515 (where the quotation from Justice Douglas is given as what "the Supreme Court of the United States in Edwards v. California, ... stated ...."), and since the Alabama court merely cited $E d z u a d s$, with no indication of reliance upon a concurrence, $42 \mathrm{Ala}$. App. at $410,166 \mathrm{So} .2 \mathrm{~d}$ at 887 , there may be doubt as to the basis for Hanson. Probably it is grounded upon the privileges and immurities clause, because the Alabama court also relied upon Zellner.

The Opinion of the Justices was cited in Hanson apparently for its holding that the governor is authorized by the state constitution "to employ such forces as are available to hin," including military forces, "to keep the peace ..." $275 \mathrm{Ala} .547,549$, 156 So. $2 \mathrm{~d} 639$, 641 (1963).

In Ex parte Lavinder the Supreme Court of Appeals of West Virginia held invalid the 
(d) Residence Tests for General Assistance Infringe the Freedom of Interstate Movement Protected By the Privileges and Immunities Clause of the Fourteenth Amendment.-With the exception of the question discussed in the next subsection, the analysis of the way residence tests for general assistance infringe a freedom of movement protected by the privileges and immunities clause of the fourteenth amendment parallels the argument made earlier ${ }^{227}$ concerning the violation of such a freedom protected by the commerce clause. The different constitutional provisions safeguarding the right do not change its parameters, in this instance. The same attempts may be made to distinguish Edwards, and the same answers may be made. ${ }^{28}$

(e) Effect of the Allowance of Residence Tests for Categorical Assistance.-Does congressional approval of limited residence tests for categorical assistance programs vitiate an argument against such stateimposed tests made under the privileges and immunities clause of the fourteenth amendment? The obvious answer miglit seem to be that Congress has no power to exempt states from the requirements of the fourteenth amendment. But the problem is not that simple. Adequate analysis hinges upon whether or not there is a relationship between the commerce power and the privilege or immunity being considered. If the right to travel interstate, protected by the privileges and immunities clause of the fourteenth amendment, is only a right to travel unhindered by states

governor's declaration of martial law in a certain county. The court held that martial law was proper under the federal constitution only where an actual state of war existed, and that such a situation could exist only with the presence of military troops in the field. $88 \mathrm{~W}$. Va. at 720,108 S.E. at 431 . In this case, martial law was being enforced by civilian officials. Probably this opinion was cited in Hanson for the proposition that the governor of a state may not, by executive order, curtail the rights of citizens under the federal constitution and regular civil laws, in the absence of an actual state of war. Constantin v. Smith is in accord, stressing that Lavinder and many other cases dealing with martial law stand for the doctrines that the courts may inquire into the state of facts alleged to justify martial law, $57 \mathrm{~F} .2 \mathrm{~d}$ at 236, and that in the absence of the necessity for such law, constitutional guarantees may not be suspended, id. at 240 . The basis for this decision is somewhat confused; the court seems to rely upon (1) the Texas Constitution and (2) the due process clause of the federal constitution. Id. at 237. Similarly, the Lavinder holding seems grounded upon an interpretation of the federal and state constitutions and state statutes, with the basic federal constitutional provision which required interpretation apparently being the war power. $88 \mathrm{~W}$. Va. at 717-21, 108 S.E. at $430-31$.

Despite the cryptic citation of authority, there seems to be no doubt that Hanson stands for the proposition that in the absence of a state of war, basic constitutional guarantees and rights under civil law may not be suspended, and that there is a constitutional right of interstate travel which is so protected. The only uncertainty about the holding is whether it relies upon the privileges and immumities clause of the fourteenth amendinent or the commerce clause. The citation of Edwards and Zellner shows that the court saw one of these clauses, probably the former, as guaranteeing such a right to travel interstate.

227 Supra subsection I, $D, 1$.

228 Supra subsection I, $D, 1, d$. 
but within the limits set by Congress acting under the commerce clause, this freedom may be abridged by a state acting pursuant to a congressional mandate which is a proper delegation of legislative power. Here, the limits set for permissible residence tests are so narrow that an argument of improper delegation is almost certain to fail. However, the better reading of the concurrences in Edward's does not tie the privilege to the commerce clause, and, as will be argued later, freedom of interstate movement is also protected against federal action. ${ }^{220}$

\section{The Privileges and Immunities Clause of Article IV}

Article IV, section 2, clause 1 of the Constitution states: "The citizens of each State shall be entitled to all privileges and immunities of citizens in the several States." This language bars discrimination by a state against a citizen of anotlier state in favor of its own citizens; ${ }^{230}$ it does not affect a state's regulation of its own citizenry. ${ }^{231}$ An older view that the clause recognized certain "natural rights" and protected citizens against another state's infringement of them, promulgated by Justice Washington in Corfield v. Coryell, ${ }^{232}$ has been rejected. ${ }^{233}$

(a) Toomer v. Witsell.-Not all discriminations against citizens of other states are barred. The Court stated in 1948 in Toomer v. Witsell:234

[T] he privileges and immunities clause [of Article IV] is not an absolute. It does bar discrimination against citizens of other States where there is no substantial reason for the discrimination beyond the mere fact that they are citizens of other States. But it does not preciude disparity of treatment in the many situations where there are perfectly valid independent reasons for it. Thus the inquiry in each case must be concerned with whether such reasons do exist and whether the degree of discrimination bears a close relation to them. The inquiry must also, of course, be conducted with due regard for the principle that the States should have considerable leeway in analyzing local evils and in prescribing appropriate cures.

The Court further cleclared that "the purpose" of the clause was "to outlaw classifications based on the fact of non-citizenship unless there is something to indicate that non-citizens constitute a peculiar source of the

229 See infra subsection II, A.

230 Slaughter-House Cases, 83 U.S. (16 Wall.) 36, 77 (1873); New York v. O'Neill, 359

U.S. 1, 6 (1959); Hague v. C.I.O., 307 U.S. 496, 511 (1939) (opinion of Roberts and Black, JJ.; there was no majority opinion).

231 Slaughter-House Cases, supra note 230 , at 77.

2326 Fed. Cas. 546 (No. 3230) (C.C.E.D. Pa. 1823).

233 Hague v. C.I.O., 307 U.S. 496, 511 (1939) (opinion of Roberts, J., with whom

Black, J., concurred); id. at 520 n.1 (concurring opinion of Stone, J.).

234334 U.S. 385, 396 (1948). 
evil at which the statute is aimed."235 This language may indicate that the state has the burden of proving a sufficient justification for a classification based on noncitizenship. Placing the burden on the state seems consistent with the aim of the privileges and immunities clause, "to help fuse into one Nation a collection of independent, sovereign States."230 A state should have the burden of justifying legislation infringing such a vital constitutional pohicy.

In Toomer the Court found no evidence that noncitizen fishermen used different fishing methods or different size boats or required more costly enforcement of fishing regulations. ${ }^{237}$ Therefore South Carohna's discriminatory regulation of commercial shrimp fishing violated the privileges and immunities clause of article IV. Even if proven, increased burdens imposed by nonresidents "would not necessarily support a remedy so drastic as to be a near equivalent of total exclusion."238

When these yardsticks are applied to assistance residence tests, a determination of constitutionality requires a showing that newcomers "constitute a peculiar source" of the high welfare bill, the general evil the tests are enacted to alleviate. ${ }^{239}$ The Court in Toomer discussed the "peculiar source" in terms of whether or not each noncitizen boat produced an impact differing in kind or degree. No examination was made of the percentage of the evil which was due to nonresidents. It is submitted that a "peculiar source" exists only where the impact of each unit is different from the impact of each citizen unit. If the Toomer test is satisfied by a showing that nonresidents produced a substantial percentage of the evil, in some states the factual situation may support a finding that welfare residence tests do not violate article IV's privileges and immunities clause. The apparently inconclusive results of existing studies will be discussed later. ${ }^{240}$

Toomer would seem to overrule, implicitly, McCready v. Virginia, ${ }^{241}$ which held that the privileges and immunities clause is not violated by exclusion of other states' citizens from planting oysters in a state's tidelands, because they are part of the common property of the state's

$235 I d$. at 398.

236 Id. at 395.

237 Id. at 398.

238 Ibid.

239 See materials cited note 147 supra. If it is argued that the purpose of assistance residence tests is to prevent an influx of the indigent, the answer is that Edwards v. Califorma, 314 U.S. 160 (1941), invalidates that purpose. If it is argued that the tests are intended to prevent an influx of the indigent persons motivated solely or primarily by a desire to obtain higher assistance benefits than those available in their former state, the residence test is invalid as too broadly drawn. See infra subsection $I, E$.

240 See infra subsection I, $E$.

24194 U.S. 391 (1876). 
citizenry. While the Court in Toomer carefully distinguished $\mathrm{MC}_{\mathrm{C}}$ Cready, ${ }^{242}$ the reasoning of the Toomer opinion, especially the "peculiar source" test, undermines $\mathrm{McCready}$ and cases following it. ${ }^{243}$

The death knell of the common property doctrine was sounded in Toomer:

The whole ownership theory, in fact, is now generally regarded as but a fiction expressive in legal shorthand of the importance to its people that a State have power to preserve and regulate the exploitation of an important resource. And there is no necessary conflict between that vital policy consideration and the constitutional command that the State exercise that power, like its other powers, so as not to discriminate without reason against citizens of other States. ${ }^{244}$

The decline of $\mathrm{McCready}$ is further illustrated by Anderson v. Mullaney ${ }^{245}$ and Brown v. Anderson, ${ }^{246}$ two recent federal cases already discussed, ${ }^{247}$ which invahidated on commerce clause grounds-and in the latter, alternatively, under article IV's privileges and immunities clauselicense fees and fishing regulations discriminating against nonresidents. On the privileges and immunities issue Brown followed Toomer, ${ }^{248}$ which the judge states "put at rest" the common ownership theory of $\mathrm{MC}$ Cready. ${ }^{249}$ More important was Brown's rejection of the contention that the statute was "a reasonable regulation" because "it provides a means to prevent or alleviate the possible destitution of the residents of the State of Alaska," who "could become a burden upon the citizens of Alaska and not on non-residents." 250 The judge stated: "There is no exception in the privileges and immunities clause providing for differentiation on the basis of the general welfare of citizens of any State. . . We cannot agree with defendants that there is any authority to avoid the effect of the privileges and immunities clause solely under the guise of avoiding economic losses to residents. ${ }^{2261}$ This language, although

242334 U.S. at 401.

243 E.g., Patsone v. Pennsylvamia, 232 U.S. 138 (1914). In this case, Justice Eolmes writing for the Court used the "peculiar source" terminology, id. at 144, but was much less willing than the Court in Toomer to examine the factual basis for concluding tbat a certain group could be so described. $I d$. at 144-45.

244334 U.S. at 402.

245191 F.2d 123 (9th Cir. 1951) (one judge dissented on other grounds), aff'd on other grounds sub nom. Mullaney v. Anderson, 342 U.S. 415 (1952).

248202 F. Supp. 96 (D. Alaska 1962).

247 See supra subsection II, $D, 1, e$.

248202 F. Supp. at 101-02. Earlier in the opinion, the judge quotes the privileges and immunities clauses of both article IV and the fourteenth amendment, id. at 100, and thereafter does not identify which clause he is applying. But his reliance on Toomer makes it clear that he means the article IV clause.

249 Id. at 102 .

$250 \mathrm{Id}$. at 101-02.

251 Id. at 102 . 
applied to a different constitutional provision, is similar to that in $E d-$ wards and appears directly relevant to the assistance resident test situation.

(b) Residence Tests for Voting-A Valid Analogy?-Dictum by the Supreme Court in Blake v. McClung, ${ }^{252}$ in 1898, supports the validity of residence tests for voting and office-holding in the face of an attack under the privileges and immunities clause of article IV. The first Justice Harlan stated that a citizen of one state is not entitled, by that clause, "to enjoy in another State every privilege that may be given in the latter to its own citizens. There are privileges that may be accorded by a State to its own people in which citizens of other States may not participate except in conformity to such reasonable regulations as may be established by the State. ${ }^{.253}$ One of the examples of a permissible requirement that he then noted was a state-imposed period of residence test for voting and office-holding. ${ }^{254}$

Since these situations are easily distinguishable from the welfare test, in regard to both the state's interest necessitating the test and the impact of the test on the migrant, this dictum does not raise any serious barrier to the conclusion that welfare residence tests violate article IV's privileges and immunities clause. The voting analogy will be discussed later in this article ${ }^{255}$ since the more recent cases deal with the equal protection clause.

(c) Are Paupers Protected by the Clause?-The provision in the Articles of Confederation ${ }^{256}$ parallel to the privileges and immunities clause of article IV of the Constitution expressly excluded from its shelter "paupers, vagabonds, and fugitives." This exception was not included in the constitutional provision.

Confusion may arise from the Supreme Court's statenient in United States v. Wheeler ${ }^{257}$ that "the text of Article IV, sec. 2 of the Constitution, makes manifest that it was drawn with reference to the corresponding clause of the Articles of Confederation and was intended to perpetuate its limitations." It seems unlikely that the Court was referring to the exception of paupers and others. The quoted language appears in a discussion which (1) twice refers to the "limitation" in the Articles"

252172 U.S. 239, 256 (1898) (7-2 decision). Subsection I, $E, 7$ infra discusses recent cases which seem to indicate that the equal protection clause of the fourteenth amendment is not violated by short residence tests for voting.

253172 U.S. at 256.

254 Ibid.

255 See infra subsection $I, E, 7$.

256 Articles of Confederation, art. IV, § 2; see TENBROEK 12.

257254 U.S. 281, 294 (1920). (Emphasis added.) 
provision which inhibited the states from discriminating, ${ }^{258}$ and (2) logically can be read with the limitations perpetuated meaning this restraint on discrimination. ${ }^{259}$ Also, that case involved no question requiring the Court to consider the inclusion of "paupers, vagabonds, and fugitives." There is little chance that the Founding Fathers absentmindedly omitted the exception. The following section of article IV, ${ }^{200}$ like that in the Articles of Confederation, ${ }^{261}$ deals with extradition of fugitives.

Regardless of the Court's meaning and of the intent of the Fathers, construction of the Constitution changes with the needs and views of our society, ${ }^{202}$ and since Edwards v. California ${ }^{203}$ rejected a view of the poor as "a moral pestilence," and immunities clause of article IV should be read as extending its protections to the poor.

(d) Is Discrimination Against Nere Citizens of a State Barred?-It may also be contended that the privileges and immunities clause of article IV has no bearing on the validity of residence tests, since it protects only citizens of other states, and newcomers attacking assistance residence requirements are citizens of the state where they now reside. The citizenship part of this argument is supported by the fourteenth amendment, which states, in relevant part: "All persons born or naturalized in the United States, and subject to the jurisdiction thereof, are citizens ... of the State wherein they reside." It should be noted that this provision imposes, for acquisition of state citizenship, a requirement of residence, but no requirement of any minimum period of residence.

Residence tests for welfare programs violate the privileges and immunities clause of article IV precisely because they impair the privilege of free interstate movement, since a potential migrant will face discriminatory treatment after he becomes a resident and therefore a citizen of the state he wishes to enter. In Blake v. McClung, ${ }^{265}$ Justice Harlan stated, "The Constitution forbids only such legislation affecting citizens of the respective States as will substantially or practically put a citizen of one State in a condition of alienage when he is within or when he removes to another State."286 Therefore, the clause bars certain discrimination against the new citizen who recently was a citizen of another state.

258 Ibid.

259 See $i d$. at 294-95.

260 U.S. CoNST., art. IV, $\$ 2$, cl. 2.

261 Articles of Confederation, art. IV, $\$ 2$.

262 E.g., Jackson, The Struggle for Judicial Supremacy 174 (1941).

203314 U.S. 160 (1941).

264 Id. at 177.

265172 U.S. 239 (1898).

266 Id. at 256. (Emphasis added.) 
It may be that welfare assistance is so vital to life that its denial places an otherwise eligible newcomer in a position of "alienage" and therefore is impermissible, even where the newconier remains a resident and citizen of another state. The reasons of economic policy supporting such a conclusion have already been examined in connection with the possibility of protecting, under the commerce clause, a nonresident's riglit to assistance. ${ }^{267}$

In regard to newly arrived residents, the argument for the inapplicability of the privileges and imnunities protection of article $I V$ is at the same time an argument for finding that residence tests violate the equal protection clause of the fourteenth amendment. While the latter provision speaks in terms of persons subject to the state's jurisdiction, a discrimination seems especially repugnant to the letter and spirit of the clause when it is against citizens of the state. If a state may remove itself from castigation under article IV, on the grounds that the persons discriminated against are citizens of that state, the state cannot be lieard to say the complainants are not citizens for purposes of the equal protection clause. In other words, the class of persons not protected by the article IV clause is a class whicl is protected under the equal protection clause.

(e) Conclusion.-A conclusion that article IV's privileges and immunities clause nuay be a successful means of attacking welfare residence tests must be tempered by recognition that (1) facts may exist meeting the "peculiar source" test, at least under a percentage interpretation, and (2) the analysis of discrimination against the new citizen as discrimination against another state's citizens considering becoming sucl, may not be accepted by the courts.

\section{E. Denial of Equal Protection of the Laws}

The equal protection clause of the fourteenth amendment forbids any state to "deny to any person within its jurisdiction the equal protection of the laws." The Court has niade it clear that "the guaranty of 'equal protection of the laws is a pledge of the protection of equal laws." ",208 When a state law treats classes of persons differently, it is valid only if the classifications nuade are reasonable in liglit of the statute's purpose. ${ }^{209}$

267 See supra subsection $I, D, 1, h$.

268 Skinner v. Oklahoma, 316 U.S. 535, 541 (1942), quoting Yick Wo v. Hopkins, 118 U.S. 356,369 (1886).

209 E.g., Carrington v. Rash, 380 U.S. 89, 93 (1965); Allied Stores of Ohio v. Bowers, 358 U.S. 522, 527-28 (1959), and cases cited therein; Watson v. Maryland, 218 U.S. 173,179 (1910); Bachtel v. Wilson, 204 U.S. 36, 41 (1907); see Tussman \& tenBroek, The Equal Protection of the Laws, 37 CALrF. L. Rev. 341, 344-53 (1949). 


\section{Discrimination Between State Citizens}

While the equal protection guarantee is not restricted to citizens, it should be more difficult to sustain the reasonableness of discriminations between citizens of a state than it is to uphold diverse treatment of citizens and noncitizens. The applicant for assistance, if a resident of the state, is a citizen thereof. The fourteenth amendment so declares and does not require, for state citizenship, any period of residence in the state. Residence tests, then, must pass the test of being reasonable classifications among the citizens of the same state. The question becomes whether or not it is reasonable to discriminate, in this context, against state citizens who are newcomers.

\section{A Test for the Reasonableness of a Classification}

The reasonableness of a classification may be tested, under the equal protection clause, by comparing (1) the necessity for the discrimination (that is, the importance to the state of having this diverse treatment) with (2) relevant differences in the situations of those treated unequally, and (3) the impact of the discrimination upon individual rights and other human values. The Supreme Court made it clear in Oyamav. California ${ }^{270}$ that disparate treatment may not be justified "because of some remote administrative benefit to the State."271 In other words, the rights of a class of persons may not be unduly infringed when a less restrictive statute - albeit requiring greater administrative effort-could satisfy the same needs of the state. The continued and increasing vitality of this rule is shown by the reliance on it in Carrington v. Rash, ${ }^{272}$ from which the language just quoted is taken. There the Court held that the equal protection clause was violated by a Texas constitutional provision which "prohibits 'any member of the Armed Forces of the United States' who moves his liome to Texas during the course of his military duty from ever voting in any election in that State 'so long as he or she is a member of the Armed Forces.' "273 The fundamental defect of this provision was barring military personnel from becoming Texas residents for voting purposes regardless of their intentions. The citation of Oyama supported the Court's rejection of an argument that the Texas rule was necessary to avoid the onerous administrative tasks involved in

270332 U.S. 633, 646-47 (1948).

271 Carrington v. Rash, 380 U.S. 89, 96 (1965) (7-1 decision) citing Oyama; accord, Harman v. Forssenius, 380 U.S. 528, 542-43 (1965) (8-1 decision, Harlan, J., agreeing only in part with the majority).

272 Supra note 271 .

273380 U.S. at 89, paraphrasing and quoting in part Tex. ConsT., art. VI, \& 2. 
determining which military personnel stationed in the state had a bona fide intention to become residents. ${ }^{274}$

It is appropriate at this point to consider whether or not the classifications invalidated in Oyama and Carrington should be distinguished from residence tests as involving a different defect regarding inclusiveness. This requires comparing the group covered by the statute with the class of persons connected with the mischief at which the statute is aimed. ${ }^{275}$ Several arguments indicate that Oyama and Carrington should not be so distinguished:

(1) The opinions of the Court in those cases do not indicate preoccupation with overinclusiveness or underinclusiveness. As the Court said in Carrington, the question was "whether the classifications drawn in a statute are reasonable in light of its purpose .... " "2r6

(2) The classifications in Carrington and in the residence test situation each can be viewed as either overinclusive or underinclusive. In Carrington, the Court stressed the fact that Texas had singled out servicemen, and had not applied the same rule to other groups whose bona fide residence might be in doubt. ${ }^{277}$ This would indicate underinclusiveness, but the Court also noted that Texas had been able to distinguish among servicemen, in regard to bona fide residence, for legal purposes other than voting, and this would indicate overinclusiveness. Similarly, in the residence test situation, the class treated differently is too broad if the legislature is worried about good faith residence, and the class is too narrowly drawn if the purpose of the solons is merely to reduce the number of persons eligible for welfare assistance, or to eliminate those persons whose past contributions to the state's economy do not equal all or some specific portion of the assistance sought, or to make eligible for public assistance only those persons for whoin aid from private charities is unavailable. In Oyama, the crucial issue was the basis of the classification (national origin) rather than its inclusiveness.

(3) The overriding factor is that in regard to denial of eligibility for assistance, an overinclusive classification is worse than an underinclusive one.The former will result in human suffering and, in some cases, a threat to life itself, while the latter causes, at most, waste of public funds. While such waste may result in higher taxes and some discomfort for persons, in all likelihood increased tax burdens will be borne by families other than those on the margin of subsistence. Whether the situation is viewed

274 Id. at 96 . Worry about large administrative expenditure was stressed by Justice Harlan dissenting. Id. at 99-100.

275 Tussman \& tenBroek, supra note 269 , at $345-48$.

276380 U.S. at 93, quoting McLaughlin v. Florida, 379 U.S. 184, 191 (1964).

277380 U.S. at 95-96. 
as involving overinclusiveness or underinclusiveness, the Court should apply a stricter test to classifications involving hife itself, than to those in cases hike Oyama and Carrington, involving land ownership and voting. ${ }^{278}$

(4) The Court rejected in Oyama and Carrington-both arguably cases of overiuclusive classifications, and the latter clearly having an underinclusive aspect-the administrative convenience justification which, in what is probably the leading article on equal protection, is posited as applying in some underinclusive classification situations. ${ }^{270}$

It is submitted that the overinclusive-underinclusive distinction is not helpful in regard to assistance residence tests. Analysis should depend upon the need for and purpose of the classification, relevant differences in the situations of those treated differently, and the impact of the discrimination upon individual rights and other human values, most especially, hife itself.

\section{Oyama v. California}

The decision of the Supreme Court in Oyama v. California ${ }^{280}$ is relevant to the question of the compatibility of assistance residence tests with the equal protection clause of the fourteenth amendment. The majority held violative of that clause and of the privileges of United States citizens, a Cahifornia statute which, in effect, imposed different presumptions regarding property ownership upon the class of minor citizens whose parents were aliens incapable of naturalization. "The cumulative effect ... was clearly to discriminate against Fred Oyama. He was saddled with an onerous burden of proof which need not be borne by California children generally."281 "Thus, as between the citizen children of a Chinese or English father and the citizen children of a Japanese father, there is discrimination . . . ."282 The privilege of citizens violated was that of owning land. ${ }^{283}$ While the majority also gave this second ground for their holding, they depended primarily upon the equal protection clause. ${ }^{284}$ That guarantee was also relied upon by the

278 The distinction is even more obvious between the assistance situation and cases involving economic regulation, such as Railway Express Agency v. New York, 336 U.S. 106 (1949), where the Court upheld a statute barring advertising on trucks except for advertisements of goods sold by the truck's owner.

279 Tussman \& tenBroek, supra note 269 , at 349.

280332 U.S. 633 (1948).

281 Id. at 644

282 Id. at 645

283 Id. at $640,646-47$;

284 Most of the majority's analysis is devoted to this issue, id. at $640-47$. The right to own land seems to have been relevant only to undercutting any justification for the unequal treatment. $I d$. at 64 
four concurring justices, being the only provision cited by Murphy and Rutledge, ${ }^{285}$ and a major basis for the opinion of Black and Douglas. ${ }^{286}$ Reed and Burton, ${ }^{287}$ and Jackson in a separate opinion, ${ }^{288}$ dissented on the ground that it is anomalous to find the presumptions unconstitutional, while assuming the validity of the underlying provisions of the California Alien Land Law forbidding aliens to own land if they were ineligible for American citizenship. The thrust of the presumptions was aimed at sucl alien parents to prevent them from evading the law by holding property in the names of citizen children. ${ }^{289}$

In Oyama, the invalid discrimination was based upon the parent's status as an alien of particular descent, that is, upon the status of a person who, althougln a resident, was not and could not become a citizen of the state. The fourteenth amendinent requires United States citizenship as a prerequisite for state citizenship; at the time Oyama was decided, Japanese nationals were not eligible for naturalization. ${ }^{200}$ Residence tests for assistance posit a difference in treatment upon what may well be an even more invalid basis: the status of one who recently became a resident and state citizen.

Oyama may be distinguished because the discrimination is vested upon the child because of the parent's status. But while the Court expressly found no need to decide if the statutory presumptions denied equal protection to the parent, ${ }^{201}$ or if the ban on alien landholding was similarly invalid, ${ }^{292}$ affirmative answers seem indicated by the rationale of the decision, by the language of the fourteenth amendment requiring states to give equal protection of the laws to all persons subject to their jurisdiction and not just to citizens, and by the fact that four concurring and three dissenting justices would have faced these questions.

Oyama does contain an indication that the majority holding should

285 Id. at 65

286 Id. at 647. Black and Douglas, the only deciding Justices now on the Court, would have decided the case "on the broader grounds that the basic provisions of the Cahfornia Alien Land Law [forbidding aliens to own land] violate the equal protection clause of the Fourteenth Amendinent and conflict with federal laws and treaties governing the immigration of aliens and their rights after arrival in this country," ibid, and would have overruled previous decisions of the Court to the contrary, $i d$. at 649 . (The prior decisions referred to were Terrace v. Thompson, 263 U.S. 197 (1923); Porterfield v. Webb, 263 U.S. 225 (1923); Webb v. O’Brien, 263 U.S. 313 (1923); Frick v. Webb, 263 U.S. 326 (1923), all cited in 332 U.S. at 649 n.3.). Justices Murphy and Rutledge would have reached the same result, but relied only on the equal protection clause. 332 U.S. at 650 .

287 Id. at 674.

288 Id. at 684 .

289 Id. at 646 .

$290 I d$. at 635 n.3.

291 Id. at 647.

292 Id. at 646. 
have been, or at least could have been, based on the unequal treatment of the parent. California argued, in response to a cliarge of racial discrimination against the child, that its statute applied to any recipient of a gift from the father, Kajiro Oyama. ${ }^{298}$ The majority opinion responded that the statute made the racial descent of the father determinative, ${ }^{294}$ thereby slowing that these justices were focussing on the parent's status.

This portion of the opinion ${ }^{295}$ and express statements by two of the concurring justices ${ }^{286}$ provide a basis for distinguishing Oyama as merely another case invalidating racial discrimination. But language earlier in the majority opinion seems to indicate that considerable weiglit was put upon a factor more akin to that present in assistance residence test cases; - the Court stated that the pertinent constitutional deficiency was discrimination against the child 'based solely on his parents' country of origin. ${ }^{2297}$ Similarly, the residence test penalizes those who enter from another state of the United States.

It miglit be argued that landholding is a right, whereas receipt of welfare assistance is a privilege, or a right in regard to which different standards of equal protection should apply. However, the Oyama holding can be read broadly as being based upon a state's duty to treat equally similarly situated residents of the state, regardless of their origins. If unequal treatment may not be based upon Japanese nationality, how can it be based on recent citizenship of another state of the United States, unless the time factor is to be determinative? But since a federal statute $^{288}$ granting citizens the right to own land was held in Oyama to undermine a justification based upon the father's status as an alien, ${ }^{200}$ the right of free interstate movenent-a constitutionally protected, ${ }^{800}$ and therefore higher class of, right-should serve to destroy any rationale bottomed on recent interstate migration. Moreover, in defining state citizenship the fourteenth amendment makes no distinction between newcomers and long-term residents.

\section{Arguably Valid State Purposes Served by Residence Tests for Public Assistance}

The major constitutionally pernissible state objective arguably served by a residence test for welfare assistance is avoiding having indi-

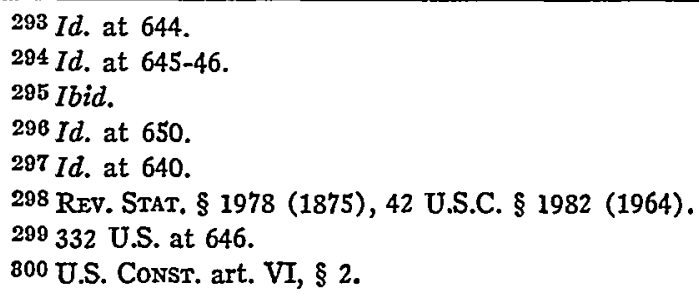


gents enter the state for the sole or primary purpose of receiving welfare. While the Court did not reach the equal protection argument in Edwards v. California, ${ }^{301}$ the thesis underlying the majority and concurring opinions bars a state from seeking to protect the public purse by excluding, or hindering the entry of, all nonresident indigents, including those who have a reason for entering other than a desire to collect welfare. In Edwards the Court rejected California's very real argument that the influx of "Okies" and other fugitives from the impact of the Depression and Dust Bowl imposed severe costs on the state. ${ }^{302}$ It might be thought that residence tests present a better case for constitutionality than did the statute in Edwards, since they do not bar interstate movement, but only deny assistance payments for a period after arrival. Two answers exist: (1) residence tests do bar interstate movennent for some persons who are unable to exist in a new state for the required period without public assistance, and (2) the rationale of Edwards extends to state statutes which penalize, as well as those which bar, interstate movement. The statute in $E d w a r d s$ merely hindered such movement by nonresident indigents, by making it a misdemeanor to knowingly assist one to enter the state.

The next question is whether or not a legislature could reasonably find that there is any danger to the public purse from in-migrants motivated primarily by a desire to receive welfare, or even any danger from all indigents moving to the state, if Edwards were not felt to bar the state from protecting its coffers against every such migrant. It is submitted that a careful, impartial analysis must answer that the existing studies, while not conclusive, seem to indicate that in either case the threat to the public purse is not as great as advocates of residence tests often contend. The existence of a substantial threat, again in either case, seems to vary, depending on the situation in each state.

Some commentators ${ }^{303}$ have concluded that existing studies indicate that residence tests for assistance are not necessary to serve the purpose usually given as the justification for them: to protect the public purse against costs imposed by a large in-1mgration of indigents seeking or needing welfare benefits. ${ }^{304}$ However, certain studies which miglit be thought to support this view actually are inconclusive. For example, Rhode Island's

301314 U.S. 160 (1941); compare id. at 177 (the majority saying they do not have to reach other constitutional questions) and the grounds for decision given in the concurring opinions, id. at 177-81 and 181-86, with the equal protection arguments made, 86 L. Ed. 120, 122.

302314 U.S. at 173.

${ }^{303}$ E.g., Leet, Rhode Island Abolishes Setilement, 18 Soc. SERv. REv. 281, 283-84 (1944); Falk, Social Aciion on Settlement Lawes, 18 Soc. SERv. REv. 288, 294 (1944); see LoGatto 106-07.

304 See supra note $14 \%$. 
experience, during World War II, with abolishing all settlement and residence tests and finding that welfare costs declined despite the fact that Rhode Island paid higher welfare benefits than surrounding states, ${ }^{305}$ neither proves nor disproves the efficacy of the tests. The period 1942-44 was a time of very high and rising employment resulting from the demands of war production combined with the presence of about fifteen million men in the armed services. ${ }^{306}$

Even if a state abolished residence tests and found that its welfare costs increased, this would not prove that people came to the state to get higher assistance. The increase might be attributable to persons previously deterred from moving to the state by unwillingness to lose welfare benefits for which they were presently eligible in another state. Such persons would move once the new state allowed them to obtain the same level of benefits.

Any statement that a State Welfare Department was "unable to locate a single individual who has moved into the state in order to secure assistance"307 cannot be accepted without serious doubts about the manner in which the Department sought to locate such persons. It would be naive to believe that indigents are so honest or so untutored in the answers expected by welfare agencies as to admit any such purpose, even if it were the major reason for their migration.

Doubts arise also about the interpretation which should be given to reports $^{308}$ from New York, which has no residence test. These reports show that a small percentage- $3.5 \%$ in 1946; about $1.5 \%$ in 1955-58 - of those receiving welfare in New York State had been residents for less than one year. Fair analysis must consider the effect on welfare costs, not only of each year's newcomers, but also of newcomers in the past who might have been deterred from coming to New York if the state had had a period of residence test. ${ }^{309}$ Father LoGatto has written:

The New York State Department of Social Welfare reported that in 1955 non-residents made up only $1.8 \%$ of the case load. According to

305 Reported in Leet, supra note 303, at 283-84; see also Falk, supra note 303, at 294.

306 See, e.g., Morison \& Comomager, 2 The Growth of the American Republic 686-87 (4th ed. revised 1956). Fleet's article, supra note 305 recognizes the effect of war production in creating jobs and reducing welfare costs, $i d$. at $283-84$, and notes that in Rhode Island in the year after elimination of the settlement and residence requirements for public assistance, the percentage reduction in the public assistance rolls was "jnst a little bit more than the drop for the entire nation." Id. at 283 .

307 Leet, supra 303, at 283.

308 New York State Dep't of Welfare, The Movement of Population and Public Welfare In New York State 13 (1958); N.Y. Times, Feb. 16, 1961, p. 21, col. 5, cited in LoGatto 107 n.38; New York State Ass'n of Councils and Chests, "Residence" as a Requirement for Public Assistance, Memorandum No. 1, Dec. 1956, cited in LoGatto 107 nn. 37, $39-40$.

309 See LoGatto 107. 
testimony presented last year [1961], only $1.5 \%$ had not lived in the state for a period of one year.

As for duration of dependency, and this is an important consideration since an annual increase of even $1.5 \%$ per year could reach a staggering proportion in time, it was found in New York City that the average duration of assistance to non-residents was six months for state charges and ten months as to local charges or a total of sixteen months. It must be borne in mind here that this average included such cases as aid to dependent children, aid to the blind, and old age assistance which generally are long term cases. In upper New York State, a study revealed an average length of care of fourteen months. To round out the picture, the same study shows about $18 \%$ of the $1.8 \%$ of needy non-residents require help over a long period of time..$^{310}$

An example will illustrate how the increases might accumulate. If $18 \%$ of $1.8 \%$ per year, or $.324 \%$, is multiplied by a period of ten years, the result is a $3.24 \%$ increase in welfare costs, assuming that cost per needy nonresident is the same as cost per needy resident. To this must be added the $1.8 \%$ entering eacl year and requiring an average of more than one year of assistance, for a total increase exceeding $5 \%$ in an eleven year period. A portion of those entering, who would be deterred by a residence test, will have children who will also require welfare assistance, but who will be counted statistically as residents if born of resident parents. According to a 1962 report by Greenleigh Associates, in New York, of families receiving Home Relief, Aid to Dependent Children, or Aid to the Disabled, in about twenty-five per cent of the cases the head of the household had parents who had been welfare recipients. ${ }^{311}$ This report also indicates, in a backhanded way, that newcomers do place a noticeable burden on New York's welfare programs: "The pubhic assistance recipients are not newcomers to New York State. Many are natives and at least eighty per cent have lived in the state more than five years." ${ }^{212}$ Moreover, in New York many eligible for assistance do not receive it. ${ }^{313}$ It is realistic to assume that newcomers are in this category in numbers disproportionate to the percentage of newcomers on welfare rolls or among the poor generally. It is the recent migrant who is most likely to be

310 Ibid., citing New York State Ass'n of Councils and Chests, supra note 308.

311 Greenteigh Associates, Report to the Moretand Comaussion on Welfare of Findings of tee Study of the Pubitc Assistance Program and Operations of the State OF NEW YORK 9 (Nov. 1962).

312 Id. at 17.

313 See Sparer, The Role of the Welfare Client's Lawyer, 12 U.C.L.A.L. REv. 361, 371 (1965). The figures cited therein deal with persons living in poverty who do not receive assistance. However, it is very difficult to believe that all of those persons are not eligible. In Westchester County "more than five times as many people are living in abject poverty as are receiving aid from the Westchester County Department of Public Welfare," according to a statement by the president of the Westchester Council of Social Agencies appearing in the N.Y. Times, Oct. 23, 1964, p. 37, col. 6, and quoted in 12 U.C.L.A.L. REv. at 371. 
unaware of the techniques and demands of living in a new environmentespecially if it is urban-including the welfare assistance eligibility requirements and application procedures of a particular city, county, or state. $^{314}$ The migrant poor in many cases lack the educational prerequisites to being able to learn quickly about these aspects of their new environment. ${ }^{315}$ And migrants, more than other indigents, lack even rudimentary political and organizational contacts which could help them apply for welfare.

Because the rationale in Edreards invalidates the objective of merely guarding the state treasury against the needs of migrant indigents, the analysis (or the numbers game) has one more step: ascertaming the impact on welfare costs of those who come to a state solely to obtain welfare. On this subject, there is little information. However, it is fallacious to argue that if there are few persons of this type who would be deterred by residence tests, this demonstrates that such tests do not liave substantial impact on interstate freedom of movement. There may be many who desire to move to another state for reasons unrelated to obtaining higher welfare payments, but who will be deterred from migrating by residence tests making them inehgible to receive in the new state the same level of assistance they are receiving in their present state. For them, losing present benefits rather than obtaining higher ones is the critical issue. Furthermore, impact on freedom of movement under a constitutional system devoted to individual rights should be measured in terms of impact on sucl freedom for each person whose situation is considered.

A fair conclusion seems to be that, in at least some states, it is not unreasonable for the legislature to conclude that a useful saving in welfare costs may be obtained by residence tests discouraging those who would enter the state solely because of its welfare programs. In New York, for example, a one per cent saving in welfare costs would amount to several million dollars. ${ }^{316}$ Perhaps future studies will demonstrate that a very small percentage of those in-inigrants who would be deterred by a residence test come solely to obtain welfare. ${ }^{317}$

314 E.g., Seligman, The Enduring Slums, in The EDitors of ForTuNe, The ExpLODING MEtropolis 95 (Doubleday Anchor ed. 1958).

315 Ibid. Governor Rockefeller has declared that the federal government should give New York City special aid to help alleviate the "educational and cultural lag among rural migrants" from Puerto Rico and the South. N.Y. Times, Nov. 20, 1965, p. 23, col. 6.

316 In 1962 a one per cent saving in New York would have been four million dollars. See GreENTEtgh Assoctates, op. cit. supra note 311, at $i$.

317 It is "the firm conviction of social workers and the New York City Commissioner of Welfare, among others, that people simply do not migrate for the purpose of receiving welfare aid." Sparer, supra note 313, at 376, citing Statement on the Proposal to Enact a Residence Law for Public Assistance, James R. Simpson (sic, for Dumpson), Commissioner of Welfare, New York City, 1959. 
Another arguably valid reason for requiring a minimum period of residence is to determine if the newcomer has a bona fide intent to reside in the state, and thereby to become a state citizen.

\section{The Arguably Valid Purposes Served by Residence Tests Can Be Met by a Statute Less Restrictive of Individual Rights}

The arguably valid purpose of preventing people from moving to a state with the primary aim of receiving higher assistance payments can be dealt with by a statute much less restrictive of individual rights and much less discriminatory than residence tests. Such a statute would bar from welfare assistance, permanently or for the period of residence now required, any person whose sole or primary purpose in entering the state was the receipt of assistance. A series of rebuttable presumptions regarding intention might be estabhished or a hist of factors to be considered in that regard might be provided. An example of such a statute, although it is possible to quarrel with the fairness of some of its details and its administration, ${ }^{318}$ is the New York Welfare Abuses Law, ${ }^{319}$ set

The three-member majority of the five-man New York State Committee on Welfare Costs (a group appoimted by Governor Rockefeller), recommended adoption of a one-year residence test, but "said it was aware that 'not too many people come to New York State simply to get the benefits of public assistance." N.Y. Times, April 30, 1965, p. 1, col. 3, D. 24 , col. 1 .

318 See Sparer, supra note 313, at 375-77.

319 N.Y. SOC. WELFARE LAW \& 139-a:

Special Provisions to avoid abuse of assistance and care.

1. Where a public welfare official has reason to believe that an applicant for home relief or aid to dependent children came into the state for the purpose of receiving such public assistance or care, he shall conduct an investigation according to the provisions of subdivisions two and three of this section to determine whether such applicant is undeserving of and ineligible for assistance in accordance with subdivision four of this section.

2. In the course of the investigation by the public welfare official to ascertain the facts supporting the application and to obtain such information as may be required by the regulations of the departinent, he slall direct his inquiry towards ascertaining whether or not the apphicant came into the state for the purpose of receiving public assistance or care and in making such inquiry the public welfare official slall expressly consider whether proof has been submitted as to one or more of the following:

a. That the applicant is gainfully employed at the time of the application, or

b. That the applicant has been gainfully employed since his arrival in the state for a period of at least one month during his first year of residence in the state, or

c. That the applicant had reasonable assurance of gainful employment before his arrival in the state, or

d. That the apphicant had reliable assurance of adequate private aid, maintenance or support or resources from relatives, friends or other sources in this state for himself and for any person dependent upon him for maintenance or support who preceded, followed or accompanied the applicant to this state, or

e. That the applicant for the first six months after his entry into the state made no application for public assistance or care, or 


\section{out in full in the footnote. While fair administration of such a statute} involves administrative difficulties, they do not seem to exceed those the

f. That in the case of an applicant who has entered the state within six months of the date of his application, such applicant entered the state for some purpose other than to receive public assistance or care.

3. In addition, where the applicant is a person who, by reason of age, physical and mental condition, is capable of working and who is or should be available for employment, he shall submit with his application a certificate from the appropriate local employment office of the state department of labor issued within a two week period from the date of lis application stating that such employment office las no order for an opening in part-time, full-time, temporary or permanent work of any kind to which the applicant could properly be referred by such office, taking into consideration only his plysical and nental capacity without reference to his custoniary occupation or acquired skill. Such a certificate, however, shall not be required of persons who cannot register with such employment office because of age, health or other disability or are otherwise not available for enmploynent.

4. If as a result of such an investigation and upon the proof submitted by the applicant, by affidavit or otherwise, the public welfare official determines that such applicant came into the state for the purpose of receiving public assistance or care and accordingly is undeserving of and ineligible for assistance, the application shall be disapproved. It shall be evidence that a person is not undeserving of and ineligible for assistance if the investigation revealed an affirmative answer to either paragraphs, $a, b, c, d, e$, or $f$ of subdivision two of this section. If in the case of a person who falls within the purview of paragraph $f$ of subdivision two of this section, the applicant fails to submit proof to the public welfare official that he entered the state for some purpose other than to receive public assistance or care, he shall be presumed to have come into the state for the purpose of receiving public assistance or care and accordingly to be undeserving of and ineligible for assistance. A person shall not be determined to be undeserving of and ineligible for assistance if a certificate as required by subdivision three of this section las been subnitted. If either home relief or aid to dependent children is granted on the basis of such a certificate, such assistance or care sliall be terminated to any person who, by reason of age, physical and mental condition, remains capable of working and who is or should be available for employment and who remains eligible for registration with the employment office if such person:

a. wilfully fails to obtain and file with the public welfare district at least once in every two-week period a new certificate of the type required to be filed in accordance with subdivision three of this section, or

b. wilfully fails to report for an interview at an employment office with respect to employment when requested to do so by such office, or

c. wilfully fails to report to such office the result of a referral to employment, or

d. wilfully fails to report for employment, or

e. refuses to accept employment for any reason other than his plyysical or mental condition.

Such wilful failures or refusals as above listed slall be reported immediately to the public welfare district by such local employnent office.

5. Notwithstanding any inconsistent provision of this section, an applicant in immediate need of public assistance or care for himself or for any person dependent upon him shall be granted such assistance or care on a temporary emergency basis.

6. If the public welfare official determines that the applicant is undeserving of and imeligible for assistance hereunder, he shall notify the applicant of lis decision in writing. 
Supreme Court, in effect, imposed on Texas in Carrington, ${ }^{320}$ if Texas wishes to contest the residence of servicemen stationed there. However, it should be noted that in Carrington the Court placed considerable emphasis upon the fact that Texas did ascertain bona fide residence for other classes of voters and for other purposes. ${ }^{321}$ It may be objected that states lack the experience necessary to demonstrate that it is possible to identify those entering solely to obtain welfare. In reply it may be said: (1) It is unclear to what extent, if any, the decision in Carrington depended upon the existence of these facts; (2) in any event, state experience in ascertaining bona fide residence is analogous; and (3) nothing in the New York experience has indicated that the task is impossible- the Welfare Abuses Law illustrates a list of factors which may be consulted. It is submitted that these contentions overcome the objection.

An even less restrictive statute, which would deal effectively with persons coming to a state solely or primarily to get higher welfare benefits than those available in their former home state, would allow newcomers shown to have such an intent, to collect only such welfare assistance as would equal that for which they were eligible in their prior state of residence. The restriction of assistance payments could be imposed permanently or only for a limited time after the arrival of the newcomer with the requisite intent.

Similarly, the rule of Oyama and of Carrington disposes of the argument that residence tests are necessary to show a bona fide intent to become a resident and state citizen. Other factors may be looked to in this regard, including those used in examining the reasons for a person's entering the state. Moreover, requiring a period of residence as a means of ascertaining a bona fide intent to reside seems incompatible with the fourteenth aunendment's definition of state citizenship, which encontpasses all residents, including those who have just arrived.

The existence of more restrained methods of handling the only arguably valid purposes of residence tests for assistance renders those tests

7. If an application is not acted upon by the public welfare official within thirty days after the filing of the application or if the applicant is determined by the public welfare official to be undeserving of and ineligible for assistance, the applicant may appeal to the department, which upon receipt of the appeal shall review the case, shall give the applicant making the appeal an opportunity for a fair hearing thereon and within thirty days render its decision. The department may also, on its own motion, review any such decision made, or any case in which a decision has not been made by the public welfare official within the time specified. All decisions of the department shall be binding upon the public welfare districts involved and shall be complied with by the public welfare officials thereof. 320 See Carrington v. Rash, 380 U.S. 89, 96 (1965). 321 Id. at $95-96$. 
violative of equal protection under the tests laid down in Oyama and Carrington.

Fairness would seem to require that statutes like those suggested should place the burden of proof on the state to show that obtaining welfare was the sole reason for entering the state. So structured and administered in good faith, such a statute should avoid the harmful aspects of residence tests while still safeguarding the public purse insofar as is constitutionally permissible.

Worries that such a statute might be unfairly administered so as to discriminate against newcomers raise a legislative rather than a constitutional question. The courts must assume bona fide application of statutes until the contrary is shown. Then, it can be enjoined. Also the defect of improper administration is inherent in residence tests themselves.

\section{Are the Arguably Valid Purposes Really Valid?}

It is by no means clear that a state may deny assistance to, or reduce the level of assistance for, newcomers whose sole or primary reason for migrating was to obtain higher welfare benefits. The rationales of $E d$ wards and of the state citizenship and equal protection provisions of the fourteenth amendment seem to require that a state treat all of its citizens equally, regardless of length of residence or intent in entering the state. Furthermore, denial of assistance would contravene the freedom of movenient analysis made earlier, concluding that a state providing higher assistance benefits than the newcomer's former home state is required to provide at least the equivalent of the benefits for which he was eligible there.

It miglit be argued that when a newcomer arrives, having moved solely to obtain higher assistance payments, his "bad purpose" eliminates any need to worry about equal protection and freedom of movement in regard to him. On the other hand, the newcomer desiring higher benefits only has the purpose of beconing a citizen of a state with more humane social welfare policies. This motive seems little different from that of persons who are attracted to a state because it has better public universities, provides more aid per grade school pupil, has finer public recreation facilities, or furnishes superior services in any other area of public programs. Certainly the alleged "bad purpose" is not so evil that it should result in penahizing interstate movement and denying equal protection. Nor would the fourteenth amendment's state citizenship provision seem to allow examination of the newcomer's purpose in becoming a resident.

To this argument it might be replied that the state certainly can seek to ascertain if the newconier is a bona fide resident, and that persons migrating solely to obtain higher assistance payments do not have an 
intention to remain indefinitely, the requisite intention for becoming residents. They will leave if such payments are reduced or another state provides a more generous program. But the same may be true of persons attracted to a state by any other state program. Additionally, it can be argued that a state may not make eligibility for assistance depend on residence, since the guarantee of the equal protection clause is not limited to state citizens, but extends to all persons subject to the state's jurisdiction.

It is uncertain whether a state may refuse to extend assistance eligibility to nonresidents and to those who became residents with the purpose of obtaining higher welfare payments. It is submitted that the rule more consistent with the nature of the Federal Union, the language of Edwards, freedom of movement, and equal protection, is that a state may not so limit assistance. In any event, the arguably valid state purposes underlying such limitations may be pursued by measures less restrictive than residence tests, which therefore clearly are invalid.

Moreover, aside from constitutional requirements, the realities of welfare administration probably make it desirable for a state not to confine assistance to those becoming residents with a purpose other than that of obtaining higher assistance benefits. Investigating residence and motives for becoming residents will require the expenditure of time and money whicll might be better spent in providing services to the needy. When state administrators are applying state standards and are under pressure to conserve state resources, even the best system of presumptions designed to protect newcomers may be insufficient to prevent frequent, unwarranted findings of a sole or priniary intent to obtain higher welfare benefits or of a lack of a bona fide intent to become a resident. ${ }^{322}$

\section{The Voting Cases}

One-year residence tests for voting have been held valid in the face of attacks under the equal protection clause. Drueding v. Devlin, ${ }^{323}$ decided by a three-judge federal district court in 1964, rejected an attack upon state-imposed residence requirements for voting for President and Vice-President. Maryland required one year of residence in the state and six months in the county. ${ }^{324}$ The court found that these tests did not violate the equal protection clause of the fourteenth amendment. The judges noted (1) that many states have a one-year residence requirement and that Congress imposed such a test in implementing the twenty-

322 Sparer, supra note 313 , at 375-77.

323234 F. Supp. 721 (D. Md. 1964), aff'd per curiam, 380 U.S. 125 (1965), discussed in Feinberg 14-16.

324 MD. Const, art. I, § 1. 
third amendment, allowing District of Columbia voters to participate in Presidential elections; ${ }^{325}$ (2) that steps were being taken in Maryland to reduce the residence period required to vote in such elections, ${ }^{320}$ and (3) that the Court of Appeals of Maryland stated the purposes of the residence tests were (a) to identify the voter and protect against fraud, and (b) "to insure that the voter will 'become in fact a member of the community, and as such have a common interest in all matters pertaining to its government. ${ }^{\prime \prime 327}$ The district court holding was affirmed in a per curiam opinion by the Supreme Court. ${ }^{328}$ The strength of this affirmance as precedent may be weakened by the fact that it was rendered at a time when it was evident that voting rights legislation would be considered by Congress, ${ }^{329}$ and when steps were being taken in Maryland to reduce the residence period. The Court may have felt the time inappropriate for careful consideration of the equal protection challenge to these residence tests for voting. Also, a reversal of the three-judge court would have impliedly overruled Pope v. Williams, ${ }^{330}$ upon which it had relied. ${ }^{331}$ In Pope, a 1904 case, the Supreme Court upheld a oneyear residence test for voting in state elections, against challenges based upon the equal protection clause, freedom of movement, and the definition of state citizenship in the fourteenth amendment. ${ }^{332}$ Actually, the requirement in Pope was even more restrictive: New residents entering the state after a given date had to record their intention of becoming residents and were not allowed to vote until one year after the date of so recording. ${ }^{333}$ But the Pope holding was based on views of the right to vote in state elections in all probability not acceptable today: "A state, so far as the Federal Constitution is concerned, might provide by its own constitution and laws that none but native-born citizens should be permitted to vote . ..."334 Oddly enough, the Court made this statement

325234 F. Supp. at 725 , giving no citation but apparently referring to D.C. CoDE § 1-1102(2) (Supp. V, 1966).

326234 F. Supp. at 725: "As a result of this case the Attorney General of Maryland has recouninended to the Legislative Council that the provisions in question be annended to shorten the length of residence requirements for voting for presidential electors."

327 Id. at 724, quoting Shaeffer v. Gilbert, 73 Md. 66, 70, 20 Atl. 434, 435 (1890).

328 Drueding v. Devlin, 380 U.S. 125 (1965).

329 The Supreme Court affirmed per curiam on March 1, 1965. On March 15, 1965, President Johnson addressed a joint session of Congress and called for voting rights legislation. He transmitted the proposed bill to Congress on March 17, 1965. Christopher, The Constitutionality of the Voting Rights Act of 1965, 18 STAN. L. REv. 1, 36 (1965). However, prior to March 15, 1965, it was clear that there would be voting rights legislation considered in that session of Congress. See $i d$. at 8 .

330193 U.S. 621 (1904), discussed in Feinberg 14-15.

331234 F. Supp. at 724.

332193 U.S. at $624-25$.

333 Id. at 622 n.1.

334 Id. at 633. 
after recognizing that states could not make discriminations between individuals which violated the Constitution. ${ }^{335}$

However, the argument that the Court, in the next case, might invalidate period of residence requirements for voting is badly weakened by dictum in a 1965 opinion joined by seven justices, in Carrington $v$. Rash: "Texas has unquestioned power to impose reasonable residence restrictions on the availability of the ballot. Pope v. Williams, 193 U.S. $621 .{ }^{338}$ The present analysis must accept the hikelihood that the Court will uphold short residence period requirements for voting. Then, it is important to ascertain if there are significant reasons for treating residence tests for assistance differently. In any event, it should be noted that Pope and Drueding involved relatively short residence tests, and therefore are distinguishable when longer periods are required, for voting or welfare.

The major reasons for residence tests for voting seem to be (1) to protect against fraud, and especially against an influx of alleged "residents" immediately before a close election; and (2) to ensure that voters will have had time to become aware of community problems, the qualifications of candidates, and the respective positions of political groups. The requirement that voters have cast in their lot with the community is an amalgam of both of these objectives. ${ }^{337}$

The major reason for residence tests for assistance programs is financial-protection of the public purse by reducing welfare costs by discouraging in-migration by the indigent, and by eliminating, for each newcomer, a period of time during which he can collect assistance.

Therefore, the rationales for residence tests for voting and assistance differ, being protection of the integrity and intelligence of the voting process as opposed to protection of the public purse and the taxpayers. The effects of such tests also differ. Residence tests for voting are unhikely to deter in-migration and freedom of interstate movement, and do not involve risk to life. Residence requirements for assistance are likely to deter interstate movement by indigents, and may cause great suffering and even loss of life. Moreover, the voting requirement affects only adults, while the assistance test may penalize children who suffer because their parent or parents changed residences, a factor over which the children have no control.

335 Id. at 632 . Since the fourteenth amendment makes all native-born and all naturalized citizens of the United States also citizens of the state in which they reside, it would obviously seem to follow that the equal protection clause would be violated by the voting discrimination suggested in the quotation appearing in the text.

336380 U.S. 89, 91 (1965).

337 Schmidhauser, Residency Requirements for Voting and the Tensions of a Mobile Society, 61 Mrcr. L. REv. 823, 828 (1963); Legislation Note, Voting Rights-Residence Requirements for Voting in Presidential Elections, 18 VAND. L. Rev. 337 (1964). 
Balancing rationales against effects-and it would seem that there is a much greater need to protect the imtegrity of the electoral process than to avoid the expenditure of extra welfare dollars-leaves no doubt that it is much easier to uphold residence tests in the voting context than in the welfare area.

\section{The State's Common Property Argument}

It may be contended that the public funds of a state are the common property of its citizens, and by analogy to McCready v. Virginia, ${ }^{338}$ outsiders may be barred from participating in welfare programs paid for out of this common property. In $M c C r e a d y$, the Supreme Court held that a state holds its tidelands as the common property of its people and can prohibit other states' citizens from planting oysters thereon.

Even assuming that $\mathrm{McCready}$ is still good law, a dubious proposition in light of Toomer $v$. Witsell $b^{339}$ and other cases already discussed, ${ }^{340}$ the common property argument must fall because a residence test for welfare assistance discriminates, not against another state's citizens, but against new citizens of the state imposing the test. Any attempt to argue that the period of residence would ensure that assistance recipients would have participated in providing the public revenue upon whicli they are drawing must be rejected. There is no relationship between living in a state for a period of time and paying taxes sufficient to cover the cost of subsequent welfare aid. Soine newcomers might pay huge taxes in a short time, and subsequently require hittle or no assistance. Others miglit reside for the required period without paying any taxes, and then receive welfare payments for the rest of their lives.

Also, the McCready type of situation is distinguishable from that involving residence tests for welfare, which may be essential to maintenance of life itself.

The common property argument, like the other attempted justifications previously considered, is insufficient to overcome the fourteenth amendinent's defimtion of state citizenship and guarantee of equal protection of the laws.

\section{$F$. Conclusion Regarding Residence Tests for General Assistance}

Residence tests for general assistance should be held unconstitutional under either a freedom of movement or an equal protection analysis. Since several grounds exist for finding that there is a constitutionally

83894 U.S. 391 (1876). See also Patsone v. Pennsylvania, 232 U.S. 138 (1914) (Holmes, J.); Geer v. Connecticut, 161 U.S. 519, 529 (1896).

339334 U.S. 385 (1948).

340 See supra subsection I, $D, 3, a$, for the discussion of Toomer, and subsections I, $D, 1, e, I, D, 3, a$ for discussion of other cases undermining $M c C r e a d y$. 
protected freedom of interstate movement, the Court may eventually rely, not upon any discrete constitutional clause, but upon a general right to travel with roots in several provisions. An analogous development has been that of the right of privacy, or at least of marital privacy, as was evidenced by Griswold v. Connecticut. . $^{341}$

If neither the infringement of freedom to move interstate nor demial of equal protection is held to be sufficient to invalidate residence tests for general assistance, the cumulative impact of such tests on these two vital constitutional safeguards should provide an adequate basis for such a holding.

\section{II}

THE CONSTITUTIONALITY OF RESIDENCE TESTS FOR CATEGORICAI ASSISTANCE PROGRAMS

For categorical assistance programs under the Social Security Act, Congress allows himited residence requirements in state plans qualifying for federal financial participation. In regard to Old-Age Assistance, ${ }^{342}$ Aid to the Blind, ${ }^{343}$ Aid to the Permanently and Totally Disabled, ${ }^{344}$ and programs combining them, ${ }^{345}$ the Secretary of Health, Education and Welfare "shall not approve" any state plan with a residence requirement excluding "any resident of the State who has resided therein five years during the nine years immediately preceding the application for [the aid] ... and has resided therein continuously for one year immediately preceding the application." For Aid to Needy Families with Children, ${ }^{34 \mathrm{~B}}$ a state may not deny

aid with respect to any child residing in the State (1) who has resided in the State for one year immediately preceding the application for such aid, or (2) who was born within one year immediately preceding the application, if the parent or other relative with whom the child is hiving has resided in the State for one year immediately preceding the birth.

These federal standards define the permissible maximum exclusions. A state nuay have less restrictive residence tests and still qualify for federal financial participation.

Qualifying state plans for Medical Assistance to the Aged, under Title I of the Social Security Act ${ }^{347}$ or under Tiele XVI ${ }^{348}$ (where it may

341381 U.S. 479 (1965).

34249 Stat. 620 (1935), as amended, 42 U.S.C. $\S 302$ (b) (2) (1964).

34349 Stat. 645 (1935), as amended, 42 U.S.C. $\$ 1202$ (b)(I) (1964).

34464 Stat. 555 (1950), as amended, 42 U.S.C. $\$ 1352(\mathrm{~b})(\mathrm{I})$ (1964).

34576 Stat. 198 (1962), as amended, 42 U.S.C. $\$ 1382(\mathrm{~b})$ (2) (1964).

31649 Stat. 627 (1935), as amended, 42 U.S.C. $\$ 602$ (b) (2) (1964).

34749 Stat. 620 (1935), as amended, 42 U.S.C. $\$ 302$ (b) (2) (1964).

34876 Stat. 198 (1962), as amended, 42 U.S.C. \& 1382 (b) (2) (1964). 
be combined with other categorical assistance programs), and qualifying plans for Medical Assistance under Title XIX, ${ }^{340}$ must not incorporate any residence test other than a requirement of residence in the state.

This allowing of residence tests by Congress would seem to be unconstitutional only if the tests violate (1) a freedom of interstate movement protected against congressional action, or (2) an equal protection of the federal laws guarantee read into the due process clause of the fifth amendment. These residence requirements also may be invalid as products of an unconstitutional delegation of legislative power to the states by Congress. This argument seems to be merely another way of stating the federal equal protection contention. Moreover, state statutes meeting federal requirements can be held invalid as violating a freedom of interstate movement or as infringing the equal protection clause of the fourteenth amendment, according to the arguments already given in regard to state public assistance programs, with the exception of the commerce clause analysis. Congress cannot empower a state to violate the Constitution, but it can, under the commerce power, authorize state action which would otherwise violate the commerce clause. Of course, such authorization is effective only if the relevant federal statute is constitutional.

\section{A. Infringement of a Freedom of Interstate Movement Protected Against Federal Action}

Residence tests for categorical assistance infringe a freedom of movement within the United States wlich is protected against federal action by the due process clause of the fifth amendment-unless there is a sufficient justification for this interference with personal liberty.

The existence of such a freedom of interstate movement was recognized by a federal district court in 1943, in Ebel v. Drum. ${ }^{350}$ In that case, the court invalidated an order excluding an alleged pro-Nazi from "military areas comprising a large portion of the United States," stated that an exclusion order supported by military necessity would be valid, ${ }^{352}$ where the degree of restriction was reasonably related to the degree of danger. ${ }^{353}$ Judge Ford stated:

Congress . . . with its knowledge of the limitations of governmental war power . . . did not-nor could it constitutionally-authorize the imposition of such drastic restrictions as are here involved upon the right guaranteed our citizens under the Fifth Amendment to be free

34979 Stat. 349, 42 U.S.C. $\$ 1396 a$ (b) (3) (Supp. I, 1965).

35052 F. Supp. 189 (D. Mass. 1943); see Feinberg 24 n.100.

35152 F. Supp. at 190.

352 Id. at 195.

353 Id. at 196. 
from physical restraint in moving freely from state to state . . unless the exercise of the war power was reasonable and necessary at the time and place of its application..$^{354}$

The judge then held that the evidence did not warrant a finding that "a real and present danger to our military resources" existed to support the exclusion order. ${ }^{355}$

The Supreme Court at least hinted at a freedom of movement - or more precisely a right to remain, an element of such a freedom-in Korematsu v. United States, ${ }^{356}$ where the Court in an opinion by Justice Black declared that "nothing short of apprehension by the proper military authorities of the gravest imminent danger to the public safety can constitutionally justify" exclusion from the area in which one's home is located. ${ }^{357}$ Justice Murphy's dissent ${ }^{358}$ was more explicit. Finding that the exclusion order violated the equal protection clause, he stated: "It further deprives these individuals of their constitutional rights to live and work where they will, to establish a home where they choose and to move about freely." "35s

Since Kent v. Dulles, ${ }^{360}$ in 1958 , there can be no doubt that a majority of the Supreme Court has recognized the existence of a freedom of interstate movement protected under the due process clause of the fifth amendment. The holding in Kent was an interpretation of congressional intent regarding the Secretary of State's discretion in issuing passports. However, the opinion of Justice Douglas, for a majority of five, clearly recognized a freedom of movement operative in regard to travel within the United States as well as travel to foreign countries:

The right to travel is a part of the "liberty" of which the citizen cannot be deprived without due process of law under the Fifth Amendment. ... Freedom of movement across frontiers in either direction, and inside frontiers as well, was a part of our heritage. Travel abroad, like travel within the country, may be necessary for a livelihood. It may be as close to the heart of the individual as the choice of what he eats, or wears, or reads. Freedom of movement is basic in our scheme of values. ${ }^{361}$

The quotation of this passage with approval in Justice Goldberg's opinion

354 Ibid.

355 Ibid.

350323 U.S. 214 (1944).

357 Id. at 218 .

358 Id. at 233. Justice Murphy again referred to freedom of interstate movement in his concurring opimon in Ex parte Endo, 323 U.S. 283, 308 (1944).

$350 \mathrm{Id}$. at 235 .

360357 U.S. 116, 125-27 (1958) (5-4 decision); see Feinberg 23-24.

361357 U.S. at 125-26, quoted in Feinberg 23-24. 
for the Court in Aptheker v. Secretary of State ${ }^{362}$ in 1964 shows the continued viability of this freedom of movement, although Aptheker was another case dealing with travel abroad.

Aptheker held violative of the fifth amendment a federal statute which in effect "prohibits travel anywhere in the world outside the Western Hemisphere by members of any 'Communist organization,' "1803 since the statutory infringements of the right to travel exceeded those necessitated by the national security. The Court stressed that less restrictive tools were available to Congress, ${ }^{384}$ but clearly recognized the power of Congress to inhibit freedom of movement when necessary to national security. ${ }^{305}$

As recently as May 3, 1965, the Supreme Court, in Zemel v. Rusk, ${ }^{800}$ reaffirmed its view that freedom of interstate and international movement is part of the hiberty protected by the fifth amendment against being taken without due process. ${ }^{367}$

However, the fact that a liberty cannot be inhibited without due process of law does not mean that it can under no circumstances be inhibited.

The requirements of due process are a function not only of the extent of the governmental restriction imposed, but also of the extent of the necessity for the restriction. ${ }^{308}$

Justice Warren, for the majority, found grave necessities justifying restriction of travel to Cuba: (1) hindering the spreading of subversion from "the only area in the Western Hemisphere controlled by a Communist government"; ${ }^{369}$ and (2) avoiding involvement by the United States in dangerous international incidents that might arise from improper imprisonment of United States citizens in Cuba and the statutory duty ${ }^{370}$ of the President to " 'use such means, not amounting to acts of war, as he may think necessary and proper' to secure" their release. ${ }^{371}$ Warren then acknowledged circumstances in which freedom of inter-

362378 U.S. 500, 505-06 (1964) (6-3 decision, with Black and Douglas, JJ., each concurring in a separate opinion). Justice Goldberg omitted one small portion of the language quoted in the text. Justice Black would hold the entire act, of which the statute here is a part, invalid on several grounds. 378 U.S. at 518-19. Justice Douglas's separate opinion underscored the importance of freedom of movement. Aptheker is discussed in Feinberg 24.

363378 U.S. at 507.

304 Id. at 512-14.

$305 \mathrm{Id}$. at 509 .

866381 U.S. 1 (1965).

367 Id. at 14-15.

368 Id. at 14.

369 Ibid.

370 Rev. StaT. § 2001 (1875), 22 U.S.C. § 1732 (1964).

371381 U.S. at 15. 
state movement could be infringed without violating due process: "[T] hat freedom does not mean that areas ravaged by flood, fire or pestilence cannot be quarantined when it can be demonstrated that unlimited travel to the area would directly and materially interfere with the safety and welfare of the area or the Nation as a wlole." 372 The stringency of the necessity required is shown by the next two sentences. "So it is with international travel. That the restriction which is challenged in this case is supported by the weightiest considerations of national security is perhaps best pointed up by recalling that the Cuban missile crisis of October 1962 preceded the filing of appellant's complaint by less than two months."'37s

Residence tests for categorical assistance hinder and penalize interstate migration, thereby infringing freedom of interstate movement, in the same way that residence tests for general assistance do. ${ }^{374}$ Since freedom of interstate movement may be abridged by Congress for sufficiently compelling reasons, it is imperative to consider what congressional purposes could underlie the permissive residence test provisions for categorical assistance. Perhaps Congress wished to allow a state to deter needy persons from migrating there in order to receive categorical assistance benefits. ${ }^{375}$ This purpose should not include a desire to bar the uprooted from categorical assistance; instead it slould be limited to protection of the state's treasury. In a federal nation, programs largely federally financed slould not be designed to exclude recent interstate migrants. As will be discussed shortly, such a discrimination is unreasonable and therefore violative of the equal protection gnarantee inherent in the due process clause of the fifth amendment. ${ }^{376}$ Since the purpose should be only to protect state treasuries, Congress could use a means less restrictive of freedom of movement-federal payment of the entire costs of categorical assistance for newcomers. Therefore, the categorical assistance residence test provisions suffer from the same deficiency as the statute in Aptheker: an inhibition of freedom of Inovement which exceeds that necessitated by permissible congressional objectives.

Moreover, the desire to protect state funds against an influx of the indigent would also seem to be an improper basis for limiting freedom of interstate movement, in light of the majority opinion in Edwards v. California. ${ }^{377}$ Since liealth quarantines may be a justification for infringing

372 Id. at $15-16$.

$373 \mathrm{Id}$. at 16.

374 See supra subsection I, $D$.

375 But see supra note 179.

376 See infra subsection II, $B$.

377314 U.S. 160, 173 (1941). 
freedom of movement, it is important to note that in Edwards the Court rejected the view of the poor as a "moral pestilence."

Any argument that Congress may have intended its allowance of residence tests to bar newcomers from categorical assistance until (1) they have been in a state long enough to contribute to its economy and hence to the tax base from which the state's share of such assistance is drawn, or (2) they have exhausted the possibilities of aid from private charity, iguores the fact that residence tests are unrelated to either goal. If Congress intended to discourage interstate movement, its purpose was invalid.

The importance of freedom of movement in the hierarchy of constitutionally protected rights is shown by Justice Goldberg's citation, in Aptheker, ${ }^{379}$ of first amendment cases ${ }^{380}$ to support the Court's examination of the statute on its face, "since freedom of travel is a constitutional liberty closely related to rights of free speech and association." ${ }^{381}$ Concurring in Aptheker, Justice Douglas wrote:

We noted in Kent v. Dulles ... that "freedom of movement," both internally and abroad, is "deeply engrained" in our history. I would not suppose that a Communist, any, more than an indigent, could be barred from traveling interstate. ... If, as I think, the right to move freely from State to State is a privilege and immunity of national citizenship (see Edwards v. California, 314 U.S. 160, 178), none can be barred from exercising it, though anyone who uses it as an occasion to commit a crime can of course be punished. But the right remains sacrosanct, only illegal conduct being punishable. ${ }^{382}$

Douglas then details the importance of freedom of movement and severely restricts the power to interfere with it:

Freedom of movement, at home and abroad, is important for job and business opportunities-for cultural, political, and social activities-for all the commingling which gregarious man enjoys. . . .

Freedom of movement is kin to the right of assembly and to the right of association. ...

War may be the occasion for serious curtailment of liberty. Absent war, I see no way to keep a citizen from traveling within or without the country, unless there is power to detain him. ... This freedom of moveinent is the very essence of our free society, setting us apart. ${ }^{383}$

378 Id. at 177 .

379378 U.S. at 516-17. Justice Douglas, concurring, agreed that freedom of movement was closely related to first amendment rights. $I d$. at 520 . The dissenting opinion of Justice Clark attacked this use of first amendment cases. Id. at 523 .

380 NAACP v. Button, 371 U.S. 415 (1963); Thornhill v. Alabama, 310 U.S. 88 (1940).

381378 U.S. at 517 .

382 Id. at 519.

383 Id. at $519-20$. 
It is submitted that there is no reason of sufficient importance to justify congressional sanction of residence tests for categorical assistance. Such tests are an unconstitutional infringement of interstate freedom of movement.

\section{B. Denial of the Equal Protection Guarantee Incorporated in the Due Process Clause of the Fifth Amendment}

\section{The Scope of the Guarantee}

Since Bolling v. Sharpe ${ }^{384}$ there has been no doubt that the due process clause of the fifth amendment includes an equal protection guarantee applicable to federal action. While Bolling involved racially segregated sclrools, the Court has leeld that this equal protection requirement also bars an unreasonable classification not based on race. In Schneider $v$. Rusk, ${ }^{385}$ the majority invalidated a portion of the Immigration and $\mathrm{Na}$ tionality Act of 1952 which removed the citizenship of a naturalized citizen "having a continuous residence for three years in the territory of a foreign state of which he was formerly a national or in which the place of his birth is situated, ${ }^{1386}$ unless lie resided there while employed by the Umited States.

This statute proceeds on the impermissible assumption that naturalized citizens as a class are less reliable and bear less allegiance to this country than do the native born. This is an assumption that is impossible for us to make. Moreover, while the Fifth Amendment contains no equal protection clause, it does forbid discrimination that is "so unjustifiable as. to be violative of due process." Bolling $v$. Sharpe, 347 U.S. 497, 499.387

The dissenting opinion ${ }^{388}$ of Justice Clark, joimed by Justices Harlan and White, did not contest the majority's reading into the due process clause of the fifth amendment an equal protection guarantee against unjustifiable discrimination. The dissenters merely contended that the classification in this case satisfied the test of being "reasonably devised to meet a demonstrated need." ${ }^{380}$

A view of fifth amendment equal protection, broader than a bar on

384347 U.S. 497 (1954); accord, Colorado Anti-Discrimination Comm'n v. Continental Air Lines, 372 U.S. 714, 721 (1963) (dictum) ( a federal statute requiring that job applicants be turned away because of race would violate the due process clause of the fifth amendment). 385377 U.S. 163 (1964) (5-3 decision); see Naden, Equal Protection and Federal Incorporation of State Standards in Federal Legislation: A Tough Proposition 4-5, 1965 (unpublished paper prepared for the Welfare Law Seminar taught at New York University School of Law, Fall 1965).

38666 Stat. 269 (1952), 8 U.S.C. § 1484 (1964).

387377 U.S. at 168 .

$388 \mathrm{Id}$. at 169.

380 Id. at $176-77$. 
racial discrimination, is also evident from two other dissents. The dissenting opinion of Black, Warren, and Douglas in Pennsylvania R.R. v. $D a y,{ }^{390}$ argued that the Railway Labor Act, ${ }^{391}$ as construed to allow the railroad, but not the employees, an adjudication of wage claims before a judge and jury, after an initial determination at an administrative hearing, "denies eniployees equal protection of the law in violation of the Due Process Clause of the Fifth Amendment." ${ }^{392}$ Furthermore, Black indicated $\mathrm{m}$ his dissent in Griswold v. Connecticut, ${ }^{393}$ that

Bolling v. Sharpe ... merely recognized what had been the understanding from the beginning of the country, an understanding shared by many of the draftsmen of the Fourteenth Amendment, that the whole Bill of Rights, including the Due Process Clause of the Fifth Amendment, was a guarantee that all persons would receive equal treatment under the law. ${ }^{394}$

It is apparent that the Court does not regard the equal protection aspect of fifth amendment due process as limited to barring racial discrimination. This conclusion is buttressed by the diverse instances in which lower federal courts have cited Bolling in considering whether or not federal action denied the equal protection guaranteed by the fifth aniendment. ${ }^{305}$

\footnotetext{
390360 U.S. 548,554 (1959).

39144 Stat. 577 (1926), as amended, 45 U.S.C. $\$ 151-63$ (1964).

392360 U.S. at 554.

393381 U.S. 479,507 (1965).
}

394 Id. at 517 n.10. However, Justice Black's view of $\cdot$ Bolling may have been tempered by the context in which it was expressed; he was attempting to refute a citation of that case as supporting what Black read as an argument "that judges have power to use a natural law due process formula to strike down all state laws which they think are unwise, dangerous, or irrational." Ibid.

395 These situations, other than racial discrimination, include the following: (1) a special Selective Service category for doctors, Bertelson v. Cooney, 213 F.2d 275 (5th Cir. 1954) (upheld as reasonable); (2) construction of a statute resulting in "differentiation tax-wise between partnerships organized in states adhering to the common law, non-entity, view and partnerships organized in states following the civil law, entity view," Stagg, Mather \& Hough v. Descartes, 244 F.2d 578, 582 (Ist Cir. 1957) (this construction rejected); (3) discrimination regarding National Labor Relations Board action between cases involving chain restaurants and those of hotel chain restaurants similarly involved with interstate commerce, NLRB v. Gene Compton's Corp., 262 F.2d 653 (9th Cir. 1959) (no evidence of such discrimination found) ; (4) "exempting industrial gas [gas sold by a pipeline company to a distributing company for resale for industrial purposes only] from the Federal Power Commission's power to suspend rates and ... from the discretionary power of the Commission to require security from the supplier to make reparations in cases where new rates are set aside by the Commission as unreasonable after the period of suspension has expired," where these exemptions did not apply to nonindustrial gas, Pacific Natural Gas Co. v. FPC, 276 F.2d 350, 353-54 (9th Cir. 1960) (upheld as reasonable); (5) electoral apportionment favoring one regional class of a territory's voters over another, Dyer v. Kazuhisa Abe, 138 F. Supp. 220, 227 (D. Hawaii 1956) (held: violation of fiftl amendment due process; alternative holding: denial of equal protection, which was guaranteed by the Organic Act of Hawaii, 
Of special interest to the present inquiry are cases in which federal courts have discussed discriminations involving indigents. In Henderson v. United States, ${ }^{396}$ a federal district court held that where no funds were available to pay for a free transcript, although a federal statute ${ }^{397}$ provided for furnishing one, for an indigent appealing a federal criminal conviction, the judgment and sentence must be vacated. Citing Bolling, the judge stated, "While the states are prohibited by the Equal Protection Clause of the Fourteenth Amendment from effectively discriminating against indigent petitioners in collateral proceedings, the same prohibition is imposed in federal proceedings by the Due Process Clause of the Fifth Amendment." 398

In Hyser v. Reed, ${ }^{399}$ two judges of the District of Columbia Circuit, concurring in part and dissenting in part, construed a statute ${ }^{400}$ to avoid the fifth amendment due process problems entailed by a reading not allowing the appointment of counsel to represent indigent parolees at parole revocation hearings.

The Supreme Court has repeatedly held that in criminal trials, discrimination "on account of poverty" is as unjustifiable as discrimination "on account of religion, race, or color," because it "bears no rational relationship to a defendant's guilt or mnocence." ... Poverty bears no more relationship to the question of parole violation than to the question of guilt. Therefore congressional discrimination against parolees who camiot afford counsel would raise serious problems of due process of law. To avoid such problems we should construe the statute to provide for the appointment of counsel for such parolees. ${ }^{401}$

In Fulwood v. Clemmer, ${ }^{402}$ another concurrence in the District of

31 Stat. 141, as amended) ; (6) different treatment, under a nonretroactive statute, regarding inheritance of illegitimate children resulting from adultery who were born before a certain date, Marquez v. Aviles, 252 F.2d 715 (1st Cir. 1958) (held: not unreasonable to enact statute which was not retroactive); and (7) different treatment regarding punishment and control "of persons over and those under twenty-two years of age" convicted of a misdemeanor, Cunningham v. United States, 256 F.2d 467, 472 (5th Cir. 1958) (upheld different treatment of youthful offenders as reasonable).

396231 F. Supp. 177 (N.D. Cal. 1964); see Naden, op. cit. supra note 385, at 5-6.

39728 U.S.C. $\S 753$ (f) (1964).

398231 F. Supp. at 178 .

399318 F.2d 225 (D.C. Cir. 1963).

40018 U.S.C. § 4207 (1964).

401318 F.2d at 255 (Bazelon, C.J., and Edgerton, J., concurring in part and dissenting in part). The majority, Judge Washington concurring, and Judges Fahy and Wright concurring in part and dissenting in part, did not believe appointment of counsel was necessary, but regarded the question as solely one of procedural due process. $I d$. at 238-39, 247-48, 260, 262 . Judge Wright also declared in a separate opinion that he "would have a probation officer appointed to assist in [the parolee's] ... defense if he denies the charges and is not represented by counsel." Id. at 262 .

402295 F.2d 171 (D.C. Cir. 1961). 
Columbia Circuit stated in dictum that, because of the equal protection requirement incorporated in fifth amendment due process, "it may follow that a federal court's refusal to file the non-frivolous petition of an indigent in circumstances in which a non-indigent might file would deny a constitutional right." ${ }^{\prime 403}$

\section{Denial of Equal Protection by Residence Tests for Welfare Assistance}

There are two reasons why federally sanctioned residence tests for welfare assistance may violate the equal protection of the laws guaranteed by the due process clause of the fifth amendment: (1) They are an unreasonable classification between new residents and other citizens of a state, and, generally, between recent migrants and more settled persons throughout the country, and (2) they discriminate unreasonably among new residents of different states.

(a) An Unreasonable. Classification Between New Residents and Other Citizens of a State.-Supporting the first proposition is the argument already stated in regard to state-imposed residence tests and the equal protection clause of the fourteenth amendment.

Possibly a classification must be more unreasonable to violate the equal protection guarantee of the fifth amendment due process clause than that of the fourteenth amendment. In Bolling, the Court stated:

The Fifth Amendment ... does not contain an equal protection clause as does the Fourteenth Amendment . . . . But the concepts of equal protection and due process, both stemming from our American ideal of fairness, are not mutually exclusive. The "equal protection of the laws" is a more explicit safeguard of prohibited unfairness than "due process of law," and, therefore, we do not imply that the two are always interchangeable phrases. But, as this Court has recognized, discrimination may be so unjustifiable as to be violative of due process. ${ }^{404}$

But the Court continued:

Although the Court has not assumed to define "liberty" with any great precision, that term is not confined to mere freedom from bodily restraint. Liberty under law extends to the full range of conduct which the individual is free to pursue, and it cannot be restricted except for a proper governmental objective. Segregation in public education is not reasonably related to any proper governmental objective, and thus it imposes on Negro children of the District of Columbia a burden that constitutes an arbitrary deprivation of their liberty in violation of the Due Process Clause. ${ }^{405}$

403 Id. at 174 (Edgerton, J.).

404347 U.S. at 499.

405 Id. at $499-500$. 
In short, the fifth amendment bars classifications "not reasonably related to any proper governmental objective." This test seems to be a twin of that employed under the equal protection clause of the fourteenth amendment. ${ }^{406}$

Therefore, the better view of the due process clause of the fifth amendment is that its equal protection facet, applying to the federal government, is identical with that of the fourteenth amendment, applying to the states. As the Court said in Bolling, speaking of the fourteenth amendment's prohibition against "maintaining racially segregated public schools, it would be unthinkable that the same Constitution would impose a lesser duty on the Federal Government, ${ }^{3407}$ in regard to equal protection of the laws.

(b) An Unreasonable Discrimination Among New Residents of Different States.-Arguably, assistance residence tests discriminate unreasonably among new residents of different states because it is unreasonable for Congress to allow states to have varying residence tests for eligibility under a program involving a substantial federal financial participation. It is hard to see how such permissiveness can be reasonably related to any proper objective of the federal government.

The objective of protecting states, or allowing states to protect themselves, against a heavy influx of indigents is improper under the rationale of Edwards v. California. ${ }^{408}$ The most valid congressional motivations would be (1) a desire to allow states freedom to choose their own residence tests, (2) an unwillingness to require a state to pay its portion of the cost of assistance to a newcomer until he has lived there long enough to show a bona fide intention to become a resident, and (3) an unwillingness to require a state to pay its portion of the cost of assistance to a newcomer who migrated solely or primarily in order to obtain higher categorical assistance payments than those for which he was eligible in his former state. The first aim, while it can be supported by references to the federal nature of the Union and to the traditionally state-level and county-level character of settlement concepts, ${ }^{409}$ founders in the face of the unconstitutional nature of state-imposed residence tests and the increasingly national character of the country, with its growing, mobile population. The second motivation, similarly, is invalid because it contradicts the definition of state citizenship in the fourteenth amendment. The third objective could be achieved, without affecting freedom of move-

408 See supra subsection $I, E$.

407347 U.S. at 500.

$\$ 08314$ U.S. 160 (1941).

409 Mandelker, The Settlement Requirement in General Assistance, 1955 WaSH. UI.Q. $355,366-68$. 
ment or denying equal protection, by requiring that the benefits available under categorical assistance programs in all states be equivalent in purchasing power, or by having the federal government pay the entire increment in benefits, or even the entire benefits, of persons shown to have migrated with such a motive. Residence tests are much too broad, in terms of the classes they affect, just to achieve the second and third objectives.

Supporters of the himited state options for residence tests in categorical assistance programs may rely upon Supreme Court decisions, under the equal protection clause of the fourteenth ainendment, upholding state legislation applying different rules in different parts of the state.

In Salsburg v. Maryland, ${ }^{410}$ the Court held that the equal protection clause was not violated by a state statute permitting the admission, in one county, of evidence obtained by unlawful search and seizure, although the statute barred evidence so obtained, in similar gambling prosecutions in other counties. While the precise holding was rendered moot by Mapp $v$. Ohio, ${ }^{411}$ language in Salsburg seems to support the validity of discrimination between people living in different territories of the state. The Court stated:

There seems to be no doubt that Maryland could validly grant home rule to each of its 23 counties and to the City of Baltimore to determine this rule of evidence by local option. It is equally clear, although less usual, that a state legislature may itself determine such an issue for each of its local subdivisions, having in mind the needs and desires of each. Territorial uniformity is not a constitutional requisite. ${ }^{\mathbf{4 1 2}}$

The Court held that "the Equal Protection Clause relates to equality between persons as such rather than between areas." ${ }^{413}$

However, Salsburg and the cases upon which it relies are all distinguishable as involving procedural matters. ${ }^{414}$ And in Salsburg, the Court

410346 U.S. 545 (1954) (7-1 decision; Douglas, J., dissented on the grounds which would command a majority in Mapp v. Ohio, 367 U.S. 643 (1961)).

411367 U.S. 643 (1961).

412346 U.S. at 552 .

413 Id. at 551, where the Court said this proposition was established in Missouri v. Lewis, 101 U.S. 22 (1879), which stated that (1) equal protection "means that no person or class of persons shall be denied the same protection of the laws which is enjoyed by other persons or other classes in the same place and under like circumstances," $i d$. at 31 , and (2) "there is nothing in the Constitution to prevent any State from adopting any system of laws or judicature it sees fit for all or any part of its territory," ibid.

414 As already noted in the text, Salsbutrg involved the admission of evidence. Ocampo v. United States, 234 U.S. 91 (1914), challenged a denial of a right to a preliminary examination in criminal cases to inhabitants of part of the Philippine Islands, id. at 98, and relied mainly upon Missouri v. Lewis, supra note 413 , as authority. Id. at $98-99$. Missouri v. Lewis, also rehed upon in Salsburg, see supra note 413, upheld a statute requiring that appeals from part of the state go to a separate appellate court rather than to the state's supreme court. 
spoke of "the liberal legislative license allowed a state in prescribing rules of practice" 115 and recognized that "a state has especially wide discretion in prescribing practice relating to its police power, as is the case here." ${ }^{\prime 416}$

Of more assistance to advocates of territorial diversity in regard to substantive law is McGowan v. Maryland, ${ }^{417}$ decided by the Court in 1961. The majority held valid under the equal protection clause Maryland's Sunday Laws, although they permitted certain retailers in one county to sell specified merchandise on Sunday while forbidding retailers in other Maryland counties to do so. ${ }^{418}$ The justices stated:

[W] have held that the Equal Protection Clause relates to equality between persons as such, rather than between areas and that territorial uniformity is not a constitutional prerequisite. With particular reference to the State of Maryland, we have noted that the prescription of different substantive offenses in different counties is generally a matter for legislative discretion. We find no invidious discrimination here. See Salsburg v. Maryland, supra. ${ }^{419}$

While the Court's reliance upon Salsburg may be criticized, ${ }^{420} M c$ Gowan stands as Supreme Court authority supporting territorial discrimination within a state in regard to substantive law. Therefore, it is necessary to see if that case is distinguishable in significant respects from

101 U.S. at 29-32. Appeals from the separate appellate court to the state supreme court were allowed only in certain cases. Id. at 29. The other cases Ocampo cited as authority, 234 U.S. at 99, are also distinguishable as procedural cases: Hayes v. Missouri, 120 U.S. 68, 72 (1887) (criminal case; different number of peremptory challenges to jurors in capital cases in cities having a population over 100,000); Chappell Chem. Co. v. Sulphur Mines Co. (No. 3), 172 U.S. 474 (1899) (civil case; trial by jury abridged in part of state); Mallett v. North Carolina, 181 U.S. 589, 598 (1901) (criminal case; state allowed an appeal from Superior Court for the Eastern District of the state and not from such court for Western District).

415346 U.S. at 550 .

416 Ibid.

417366 U.S. 420 (1961).

418 Id. at 427 .

410 Ibid.

420 The second sentence of the quotation is an unfair use of Salsburg, bacause therein at the pages referred to, 346 U.S. at 552-53 (see 366 U.S. at 426 , the "supra" referred to in the quotation), the text notes that Maryland has prescribed "different substantive offenses in different counties," 346 U.S. at 552, and then states that such "variations" are "a matter for legislative discretion, not judicial supervision, except where there is a clear conflict with constitutional limitations," id. at 552-53. Besides this circular statement, the only basis for McGowan's citation is a footnote which lists some statutes discriminating territorially, but the list follows this statement, "without appraising their validity, but as illustrating Maryland practice, we find Flack's Md. Ann. Code, 1951, full of such examples." Id. at 552 n.8. Therefore, the main prop for the words of the McGowan majority about territorial discrimination in substantive law is flimsy. The same defect appears in the separate opinion of Frankfurter and Harlan, 366 U.S. 459, which relies on Salsburg and Missouri v. Lewis as authority for its conclusion "that the provision of different Sunday regulations for different regions of a State is not ipso facto arbitrary," id. at 537. 
the categorical assistance situation. The latter, unlike $M c$ Gowan, involves: (1) a program which in many cases will be vital to life itself, or at least to a life with the basic necessities available; (2) a benefit granted by government rather than a police power regulation; and (3) differentiation by the federal government between people in different states, rather than by a state between people in its different parts. If the equal protection guarantees under the fifth and fourteenth amendments have similar metes and bounds, the third distinction is not important. The benefit-granting nature of assistance is significant; when the federal government uses general tax revenues to meet a national problem involving need on the part of many citizens, the needy in all states should be treated alike. Certainly the federal participation would be a sufficient ground to justify congressional action banning residence tests for categorical assistance. Similarly, it is an adequate basis for the courts to compel the same result. The vital-to-life argument is still more compelling. A suit challenging residence tests for categorical assistance would be an apt place for the court to quote the following langnage from the majority opinion of the Fourth Circuit in Simkins v. Moses H. Cone Memorial Hospital: ${ }^{421}$

We deal here with the appropriation of millions of dollars of public monies pursuant to comprehensive governmental plans. But we emphasize that this is not merely a controversy over a sum of money. Viewed from the plaintiffs' standpoint it is an effort by a group of citizens to escape the consequences of discrimination in a concern touching health and life itself.

The comprehensive plan plus the vital need for the assistance should require uniformity of treatment.

Moreover, reliance upon the Court's language in $M c$ Gowan should be tempered by a reahzation that the fact situation before the justices was one where "local option" made a lot of sense. For example, manufacturing towns may well have different needs, regarding a weekly day of rest, than resort areas. No similarly strong justification for diversity between states exists in regard to the life-sustaining, largely federally-funded categorical assistance programs.

But even if $M c$ Gowan leads to a refusal to find a violation of fifth amendment due process because of diverse treatment of newcomers residing in different states, the due process clause of that amendment is still violated because Congress sanctions discrimination by the states against newcomers, as has already been argued.

\section{Conclusion Regarding Residence Tests for Categorical Assistance}

The conclusion seems unmistakable that residence tests for categorical assistance violate the Constitution in several ways: (1) they infringe a

421323 F.2d 959, 967 (4th Cir. 1963) (3-2 decision), cert. denied, 376 U.S. 938 (1964). 
freedom of movement constitutionally protected against federal action; (2) they contravene the equal protection guarantee incorporated in the due process clause of the fifth amendment; and (3) in exercising the option provided by Congress, the states infringe (a) a freedom of movement constitutionally protected against state action and (b) the equal protection clause of the fourteenth amendment, in the same manner as when states impose residence tests for general assistance. Moreover, even if none of these arguments alone is sufficient to establish the imvalidity of residence tests for categorical assistance, their cumulative impact on several constitutional protections makes clear the unconstitutionality of those tests.

While the command of the Constitution seems clear, perhaps the most politic way to dispose of residence tests for categorical assistance would be for Congress to forbid them but provide for federal payment of all costs of such assistance to persons who have not resided $\mathrm{m}$ the state for one year. ${ }^{422}$ Indeed, the reasoming of $E d w a r d s$, that the states are all part of a federal union and "inust sink or swim together, ${ }^{2 / 423}$ would indicate that the ultimate solution for the problems purported to be dealt with by residence tests should be federal legislation either (1) making all assistance programs federal programs totally funded from the national revenue, or (2) shifting the present tax structure to increase the tax revenue of the states. Under the present arrangernent, acceptance of the conclusions reached in this paper regarding freedom of movement and equal protection, may inpose severe burdens upon certain states. However, the tax structure is not decisive in examining constitutional guarantees, and $E d w a r d s$ rejected the economic contentions that would be made in arguing that residence tests for general and categorical assistance are constitutional. Hopefully, the federal union rationale which has been accepted by the Supreme Court will also find favor with Congress, and fair provisions will be made to alleviate unusual burdens borne by those states which attract large numbers of new residents.

422 See Nathanson 22-27 (including a discussion of legislation which has been introduced into Congress at various times); Hohlt 12-13; Mandelker, The Settlement Requirement in Public Assistance, 1956 WaSH. U.L.Q. 21, 49-50.

423 Edwards v. California, 314 U.S. 160, 170 (1941), quoting Justice Cardozo in Baldwin v. Seelig, 294 U.S. 511, 523 (1935). 